\title{
Cannabinoids modulate associative cerebellar learning via alterations in behavioral state
}

Catarina Albergaria, N. Tatiana Silva, Dana Darmohray, Megan R. Carey*

Champalimaud Neuroscience Program, Champalimaud Center for the Unknown, Lisbon, Portugal

* Correspondence:

Megan R. Carey

email: megan.carey@neuro.fchampalimaud.org 


\begin{abstract}
Cannabinoids are notorious and profound modulators of behavioral state. In the brain, endocannabinoids act via Type 1-cannabinoid receptors (CB1) to modulate synaptic transmission and mediate multiple forms of synaptic plasticity. $\mathrm{CB} 1$ knockout (CB1KO) mice display a range of behavioral phenotypes, in particular hypoactivity and various deficits in learning and memory, including cerebellumdependent delay eyeblink conditioning. Here we find that the apparent effects of CB1 deletion on cerebellar learning are not due to direct effects on CB1-dependent plasticity, but rather, arise as a secondary consequence of altered behavioral state. Hypoactivity of CB1KO mice accounts for their impaired eyeblink conditioning across both animals and trials. Moreover, learning in these mutants is rescued by walking on a motorized treadmill during training. Finally, cerebellar granule cell-specific CB1KOs exhibit normal eyeblink conditioning, and both global and granule cell-specific CB1KOs display normal cerebellum-dependent locomotor coordination and learning. These findings highlight the modulation of behavioral state as a powerful independent means through which individual genes contribute to complex behaviors.
\end{abstract}




\section{Introduction}

Signals relating to ongoing behavior are widely represented in the brain (Musall et al., 2019; Stringer et al., 2019; Powell et al., 2015). Sensorimotor signals can be used to monitor and refine ongoing movements, while generalized changes in behavioral state, including arousal and levels of locomotor activity, influence sensory processing and perception (Niell and Stryker, 2010; Ayaz et al., 2013; McGinley et al., 2015; Schneider and Mooney, 2015; Vinck et al., 2015; Pakan et al., 2016). Both locomotor activity and arousal modulate delay eyeblink conditioning, a form of cerebellum-dependent associative learning (Albergaria et al., 2018).

Neuromodulatory systems often directly affect behavioral state and also modulate synaptic transmission and plasticity. For example, cannabinoids are profound modulators of behavioral state, across species (Mackie, 2007; Oakes et al., 2017; Luchtenburg et al. 2019). Throughout the brain, endocannabinoids act as retrograde messengers to regulate neurotransmitter release, mainly via type-1 cannabinoid (CB1) receptors. Presynaptic $\mathrm{CB} 1$ receptors also mediate short- and long-term forms of synaptic plasticity in a wide variety of brain regions and cell types, raising the possibility that they provide a direct substrate for learning and memory (Freund et al., 2003; Mackie 2006; Chevaleyre, Takahashi, and Castillo 2006; Regehr, Carey, and Best 2009).

CB1 knockout mice (CB1KO) display a variety of behavioral phenotypes (Zimmer et al. 1999; Valverde et al. 2005). They exhibit altered feeding behavior, anxiety, and nociception (Zimmer et al. 1999; Degroot and Nomikos 2004; Ravinet Trillou et al. 2004). Notably, global CB1KOs are hypoactive, and spend less time running than their wildtype littermates (Zimmer et al. 1999; Dubreucq et al. 2010; Chaouloff et al. 2011). This hypoactivity has been attributed to the loss of $C B 1$ receptors from GABAergic neurons in the ventral tegmental area (Dubreucq et al. 2013). They also display a range of impairments in learning and memory, including spatial memory and fear conditioning (Varvel and Lichtman 2002; Marsicano et al. 2002; Pamplona and Takahashi 2006).

In the cerebellum, CB1 receptors are highly expressed in granule cells and are required for several forms of plasticity within the cerebellar cortex. They mediate short-term suppression of excitation and inhibition, which act on a timescale of tens of milliseconds to several seconds, as well as multiple forms of longterm plasticity (Soler-Llavina and Sabatini 2006; Kreitzer and Regehr 2001b; Brenowitz and Regehr 2005; Kreitzer and Regehr 2001a; Brown, Brenowitz, and Regehr 2003; Diana and Marty, 2004). In particular, CB1 receptors have been implicated in long-term depression (LTD) between parallel fibers and Purkinje cells, an oft-hypothesized, but widely debated, substrate for cerebellar learning (Albus 1971; Ito 1972; Schonewille et al., 2011; Johansson et al., 2018). Neither global CB1KOs nor granule-cell specific CB1KOs express LTD in brain slices (Safo and Regehr 2005; Carey et al. 2011).

A previous study found that global CB1KOs were impaired in delay eyeblink conditioning (Kishimoto and Kano, 2006), a form of cerebellum-dependent associative learning (McCormick and Thompson 1984; Kim and Thompson, 1997; Heiney et al. 2014). Pharmacological evidence also implicates CB1 signaling in eyeblink conditioning. Systemic CB1 antagonists impair acquisition of delay eyeblink conditioning in mice and rats (Kishimoto and Kano, 2006; Steinmetz and Freeman 2010; Steinmetz and Freeman 2020), as do both systemic (Steinmetz and Freeman 2016) and intracerebellar (Steinmetz and Freeman 2020) CB1 agonists. However, a critical role for cerebellar CB1-mediated plasticity in cerebellar learning has not been directly established.

We recently demonstrated that engaging in locomotor activity enhances delay eyeblink conditioning within the cerebellum (Albergaria et al. 2018), raising the question of whether hypoactivity could indirectly contribute to the apparent impairments of CB1KO mice in cerebellar learning. Here we find that decreased locomotor activity fully accounts for the effects of CB1 deletion on eyeblink conditioning. Moreover, both global and cerebellar granule-cell specific CB1KO mice show normal cerebellum- 
dependent locomotor learning. We conclude that the previously described effects of CB1R deletion on cerebellar learning arise as a secondary consequence of hypoactivity in CB1KOs, and not from direct effects on cerebellar plasticity. These findings highlight the modulation of behavioral state, including locomotor activity, as a powerful mechanism through which individual genes contribute to cognition and behavior.

\section{Results}

\section{CB1KOs are hypoactive and have impaired eyeblink conditioning}

We tested cerebellum-dependent delay eyeblink conditioning in global CB1KO mice and their wildtype littermates using a head-fixed apparatus with a freely rotating running wheel as previously described (Figure 1A,B; Albergaria et al., 2018). Conditioning sessions included 100 trials in which a neutral visual conditioned stimulus (CS, a white LED) was paired with an air-puff unconditioned stimulus (US). The CS preceded the US by $300 \mathrm{~ms}$ and the two stimuli co-terminated. We measured the mouse's locomotor activity continuously with an infrared sensor placed underneath the wheel (Figure 1A).

Consistent with a previous study that found impaired learning over seven acquisition sessions (Kishimoto and Kano, 2006), we found that CB1KOs displayed delayed learning, as measured by the percentage of trials that yielded learned conditioned responses (CR; Figure 1C).

When compared to their littermate controls, CB1KO mice displayed significantly less locomotor activity on the self-paced running wheel during training sessions (Figure 1D, $p=0.015$; Figure 1 - figure supplement $1 \mathrm{~A}$ ), consistent with the previously described hypoactivity of these mice (Chaouloff et al., 2011; Dubreucq et al., 2010; Zimmer et al., 1999). Similar hypoactivity was observed regardless of whether it was measured as total distance during the session (Figure 1D), running speed per trial (Figure 1 - figure supplement $1 \mathrm{~B}, \mathrm{p}=0.013$ ), $\%$ of time walking (Figure 1 - figure supplement $1 \mathrm{C}, \mathrm{p}=0.002$ ), or $\%$ of trials with ambulatory activity (Figure 1 - figure supplement $1 \mathrm{D}, p=0.007$ ). This generalized decrease in ambulation may reflect decreased arousal, as pupil sizes were also reduced in these mice (Figure 1 - figure supplement 1E, p = 0.008; (Vinck et al., 2015; Mineault et al., 2016; Reimer et al., 2014; Reimer et al., 2016).

\section{Hypoactivity in CB1KOs accounts for apparent learning deficits}

We previously showed that eyeblink conditioning is modulated by behavioral state, and specifically, enhanced by locomotor activity (Albergaria et al., 2018). We therefore asked whether the hypoactivity of global CB1KOs could contribute to their delayed learning.

Over the course of 20 training sessions, both controls and CB1KOs eventually learned the task (Figure $1 \mathrm{E}, \mathrm{F})$. Consistent with our previous study, we found that regardless of genotype, the more an animal ran on average throughout the training trials, the earlier it learned (Figure 1E; controls, black circles: slope $=-$ $0.13, p=0.04$; CB1KO, red circles: slope $=-0.12, p=0.02$; Figure $1-$ figure supplement $1 F-G$ ). Notably, CB1KOs and controls with similar levels of locomotor activity learned at similar rates (Figure 1E,F, filled circles). This relationship held for various measures of locomotor activity (Figure 1 - figure supplement 1I-L). Comparing acquisition curves of CB1KOs with comparably active littermate controls (Figure 1F, filled circles) also revealed no delays (and if anything, a relative enhancement) in learning in the CB1KOs. These results suggest that the slower average learning rate in CB1KOs is due solely to comparison with wildtype mice that are on average, more active.

Conditioned responses are not all-or-none; their amplitudes fluctuate from trial to trial and peak eyelid closure is typically timed to coincide with the presentation of the US. We analyzed the amplitude and timing of conditioned responses in CB1KOs by analyzing trials in which the CS was presented alone, without a US. Like the percentage of conditioned responses (Figure 1F), eyelid closures in CB1KOs 
(Figure 1G, red line)were smaller than the CRs elicited in the more active control animals (Figure 1G, dashed line), but comparable to their activity-matched controls (Figure 1G, solid lines). In addition, CRs of CB1KOs, like those of controls, were well-timed: they peaked at around the time that the US would have been presented (Figure 1G; see also Figure 1 - figure supplement 2).

We previously showed for wildtype mice that both session-to session and trial-to-trial variation in the amplitude of conditioned responses is positively correlated with locomotor speed (Albergaria et al. 2018). This was also true for global CB1KOs (trials: Figure 1H; sessions: Figure $1-$ figure supplement $1 \mathrm{H}$ ). At a given walking speed, $\mathrm{CR}$ amplitudes were comparable for $\mathrm{CB} 1 \mathrm{KOs}$ and their littermate controls (Figure $1 \mathrm{H})$. However, there were differently skewed distributions of locomotor speeds across trials in the two genotypes (Figure $1 \mathrm{H}$ histogram). Therefore, to quantitatively compare conditioned response amplitudes, we analyzed trials in which the animals were stationary, starting from onset of learning (Figure 1I). There was no significant difference in the amplitude of eyelid closure for stationary trials in CB1KO mice (Figure $1 \mathrm{l}, \mathrm{J}, \mathrm{K} ; \mathrm{p}=0.58$ ).

Endocannabinoid signaling mediates short-term plasticity that acts on a timescale of tens of milliseconds up to several seconds (Chevaleyre, Takahashi, and Castillo 2006; Regehr, Carey, and Best 2009). We therefore investigated whether there might be more subtle effects on learned responses on these timescales in CB1KO mice (Figure 1 - figure supplement 2). First, we investigated the timing of conditioned responses to longer (500 ms) interstimulus intervals (Perrett et al, 1993; Chettih et al., 2011). Both CB1KOs and controls exhibited well-timed CRs on CS-only trials that peaked at around the time that the US would have been delivered (Figure 1 - figure supplement 2A). There was no significant difference between genotypes in response timing for either the $300 \mathrm{~ms}(p=0.12)$ or $500 \mathrm{~ms}(p=0.24)$ interstimulus intervals (Figure 1 - figure supplement 2B). Next, we asked whether a lack of CB1 signaling could interfere with single-trial learning effects, in which response amplitudes are modulated based on the presence or absence of an air puff US on the previous trial (Figure 1-figure supplement 2C, inset; Medina and Lisberger 2008; Yang and Lisberger 2010; Khilkevich et al., 2016; Najafi and Medina 2020). Both CB1KOs and controls displayed larger amplitude CRs on trials following trials that included a puff (Figure 1 - figure supplement 2C,D). Thus, even these more subtle features of delay eyeblink conditioning, both of which have been hypothesized to result from plasticity in the cerebellar cortex, were intact in CB1KO mice.

Taken together, the results so far suggest that the apparent impairments in eyeblink conditioning of CB1KO mice, both in terms of rate and amplitude of learning, can be fully accounted for by their hypoactivity. In other words, for CB1KO mice, behavioral state as measured by locomotor activity is a stronger determinant of learning than is genotype.

\section{Externally controlling locomotor activity rescues CB1R-related learning deficits}

If impaired eyeblink conditioning in $\mathrm{CB} 1 \mathrm{KO}$ s is solely a consequence of hypoactivity, then circumventing it by externally controlling locomotion (Albergaria et al., 2018) should be sufficient to rescue learning. Indeed, placing mice on a motorized treadmill that equalized locomotor activity for all animals and trials completely restored learning in CB1KOs (Figure 2A,C). In fact, there was now a trend towards faster learning in the knockouts, although this was not statistically significant. The average amplitude of eyelid responses was not statistically different between the two genotypes under these conditions (Figure 2D,F; $\mathrm{p}=0.82)$.

To bypass possible developmental or compensatory effects of CB1R deletion (Berghuis et al. 2007) and test the effects of acute suppression of $C B 1$ receptor function, we investigated the effects of a CB1R antagonist on eyeblink conditioning on a motorized treadmill. Wildtype mice were injected intraperitoneally with the CB1R antagonist AM251 before each training session. Similar to the locomotor phenotype of CB1KO mice, acute antagonist application reduced several measures of locomotor activity 
both across and within animals (Figure 2 - figure supplement 1 ). However, there was no delay in learning in mice injected with the CB1R antagonist compared to vehicle-injected controls when tested on a motorized treadmill (Figure 2B,C). Rather, there was a trend towards faster learning in the presence of the antagonist $(\mathrm{p}=0.05)$. There was no difference in the amplitude of conditioned responses (Figure $2 \mathrm{E}-\mathrm{F}$; $p=0.32$ ). In contrast, consistent with the strong influence of levels of locomotor activity on learning, on a self-paced treadmill learning was abolished not only following CB1R antagonist administration, but also in vehicle-injected animals, which were also severely hypoactive (Figure 2 - figure supplement 2). This effect of systemic DMSO prevented us from assessing the effects of AM251 on learning on a self-paced treadmill. However, like the hypoactive CB1KOs, both vehicle and AM251-treated animals were able to walk successfully on the motorized treadmill, where we could assess the specific effects of AM251. Together, these results again point to locomotor activity, rather than CB1R function, as a critical determinant of learning.

\section{Parallel fiber CB1 receptors are not required for delay eyeblink conditioning}

Impaired eyeblink conditioning in global CB1KOs has been hypothesized (Kishimoto and Kano, 2006; Carey et al., 2011) to be due to the loss of CB1Rs from parallel fibers, where they mediate several forms of synaptic plasticity, including parallel fiber LTD (Kreitzer and Regehr, 2001a, 2001b; Safo and Regehr, 2005; Brenowitz and Regehr, 2005; Soler-Llavina and Sabatini, 2006; Carey et al., 2011). In contrast, our results instead suggest that the apparent effects of CB1R deletion on eyeblink conditioning may arise as a secondary consequence of the hypoactivity of global CB1KOs. To directly test for a role of parallel fiber CB1Rs, we tested eyeblink conditioning in mice (G6KO) in which CB1Rs were selectively deleted from granule cells within the cerebellar cortex, whose axons form parallel fiber inputs to Purkinje cells and interneurons (Figure 3A; Carey et al., 2011; Fünfschilling and Reichardt, 2002; Marsicano et al., 2003).

Delay eyeblink conditioning was intact in granule-cell specific CB1 knockout mice compared to littermate controls (cyan and blue lines, respectively; Figure 3). The rate of learning (Figure $3 \mathrm{C}, \mathrm{E}$ ), and the amplitude and timing of conditioned responses (Figure 3D,F,G; $P=0.75$ ), were all normal, both on the self-paced (Figure 3C,D) and motorized (Figure 3E-G) treadmills. Consistent with an extracerebellar source of altered behavioral state in global CB1KOs (Dubreucq et al., 2013), G6KO mice were not hypoactive (Figure 3B; $p=0.7$; Figure 3 - figure supplement 1 ).

These results demonstrate that CB1Rs on cerebellar parallel fibers are dispensable for delay eyeblink conditioning.

\section{CB1Rs are dispensable for locomotor learning}

There are many similarities between learning mechanisms for eyeblink conditioning and other forms of cerebellum-dependent learning such as motor adaptation (Raymond et al., 1996; Raymond and Medina 2018; Gao et al. 2012). However, there are also important differences, particularly in the time course of learning, which could be particularly relevant in the context of CB1-mediated plasticity, which typically acts on much shorter time scales than eyeblink conditioning, which takes days. We therefore investigated whether CB1Rs might play a role in a rapid form of cerebellum-dependent learning, locomotor adaptation on a split-belt treadmill (Figure 4; Yanagihara and Kondo 1996; Morton and Bastian 2006; Darmohray et al. 2019).

Motor coordination is generally thought to be largely spared in CB1KOs (Zimmer et al., 1999; Steiner et al. 1999; Bilkei-Gorzo et al. 2005; Kishimoto and Kano 2006; Varvel \& Lichtman, 2002). They are not overtly ataxic (Movie 1) and show normal rotarod performance at the ages tested here (Zimmer et al., 1999; Bilkei-Gorzo et al. 2005; Kishimoto and Kano 2006). However, since global CB1KOs are hypoactive, and since split-belt treadmill adaptation involves learned changes in interlimb coordination, we first performed a detailed analysis of locomotor kinematics during overground walking (Machado et al. 2015, Machado et al. 2020) to detect any potential subtle locomotor impairments in CB1KOs (Movie 1). 
Most gait parameters were normal in CB1KOs during overground walking (Figure 4 - figure supplement $1 \mathrm{~A}-\mathrm{C}$ ), although there were some subtle differences, such as paws not lifting as high (Figure 4 - figure supplement $1 \mathrm{~B}$, right) and a small tendency towards a walking gait pattern rather than a trot at lower speeds (Figure 4 - figure supplement 1C, middle). Notably, none of these locomotor differences were observed in G6KO mice (Figure 4 - figure supplement 1D-F, Figure 4 - figure supplement 2). Further, these differences do not match the pattern of deficits found in mouse models of cerebellar ataxia (Figure 4 - figure supplement 2; Lalonde and Strazielle 2007; Machado et al., 2015; Vinueza-Veloz et al., 2015; Machado et al., 2020).

In locomotor adaptation on a split-belt treadmill, animals learn to regain overall gait symmetry in response to a perturbation that imposes unequal speeds on the two sides of the body (Figure 4A). Learning is specific to measures of interlimb coordination, which compare the symmetry of gait parameters that depend on multiple limbs (Reisman et al., 2005; Darmohray et al., 2019). Individual limb parameters, such as stride length (how far forward one paw moves during a swing phase; Figure 4B-D), change abruptly upon acute changes in belt speed, but do not show learning: they remain constant throughout the exposure to split-belt walking and return to normal once symmetrical belt speeds are restored. In contrast, interlimb coordination measures, such as step length (the relative anterior-posterior distance at stance onset between a paw and its contralateral counterpart; Figure 4E-G, see Methods), show gradual improvements in symmetry throughout the split-belt period, and prominent aftereffects in the opposite direction upon its cessation (Reisman et al., 2005; Darmohray et al., 2019). These learned changes in interlimb coordination, but not the acute resetting of individual limb parameters upon splitting of the belts, are cerebellum-dependent (Morton and Bastian, 2006; Darmohray et al., 2019).

Like controls, both global and granule cell-specific CB1KOs displayed acute individual (Figure 4C,D) and interlimb (Figure 4F,G) asymmetries upon the splitting of the belts. This initial response differed in global, but not G6KO mice: individual limb stride lengths became more asymmetric (Figure $4 \mathrm{C} ; t_{(48)}=3.64, p=$ 0.007), while initial interlimb asymmetries were smaller than expected (step length, Figure $4 \mathrm{~F}, \mathrm{H} ; t_{(48)}=$ 2.63, $p=0.01$ ). Inspection of locomotor kinematics during baseline trials, when the belts were moving at the same speed, reveals subtle differences in treadmill walking that could underlie these different reactions to the splitting of the belts (Movie 2; Figure 4 - figure supplement $3 \mathrm{~A}-\mathrm{C}$ ). None of these differences were observed in granule cell-specific CB1KOs (Figure 4D,G; Figure 4 - figure supplement 3D-F; stride length: $t_{(48)}=0.20 p=0.84$; step length: $\left.t_{(48)}=-1.03, p=0.30\right)$.

Despite the variation in the acute response to the splitting of the belts, both global and granule-cell specific CB1KOs learned to walk more symmetrically over the course of exposure to split-belt walking (Figure $4 \mathrm{~F}, \mathrm{G}$, grey shaded areas; Figure $4 \mathrm{H}-\mathrm{K}$ ). Further, upon resumption of tied-belt walking, both global and granule cell-specific CB1KOs exhibited step length aftereffects in the form of asymmetries in the opposite direction (Figure 4F-K). Locomotor learning in global CB1KOs, measured as both the improvements in symmetry over the course of split-belt walking and the step-length aftereffects, was comparable to that of controls, in terms of both absolute magnitude (Figure $4 \mathrm{H}$; late - early: $t_{(48)}=0.7, p=$ 0.45 ; aftereffect $\left.t_{(48)}=-1.06, p=0.29\right)$, and in the percent of the initial error that was compensated for (Figure 4I,K; late - early: $t_{(16)}=-1.3, p=0.2$; aftereffect: $t_{(16)}=0.6, p=0.57$ ). All measures were normal in G6KOs (abs. magnitude: late - early: $t_{(48)}=0.68, p=0.49$; aftereffect $t_{(48)}=0.05, p=0.95$; \% initial error: : late - early: $t_{(12)}=1.27, p=0.22$; aftereffect $\left.t_{(12)}=-0.94, p=0.36\right)$.

Thus, despite some subtle differences in locomotor kinematics that were present in global, but not granule cell-specific CB1KO mice, cerebellum-dependent locomotor learning was intact in both global and G6KOs. 


\section{Discussion}

The well-described cerebellar circuit architecture places strong constraints on the sites and mechanisms for learning. Despite this apparent simplicity, the contributions of various plasticity mechanisms, including long-term depression between parallel fibers and Purkinje cells, to cerebellar learning remain controversial (Carey 2011; Schonewille et al., 2011; Johansson et al., 2018). Results from gene knockout experiments have contributed to these controversies (Aiba et al. 1994; De Zeeuw et al. 1998; Koekkoek et al. 2003; Schonewille et al. 2011). Several previous studies have demonstrated that cannabinoids, strong modulators of synaptic transmission that are required for several forms of plasticity, influence cerebellum-dependent associative learning (Kishimoto and Kano, 2006; Steinmetz and Freeman, 2010; Steinmetz and Freeman, 2020). Here we show that this influence is exerted indirectly, through alteration of behavioral state; CB1 receptors themselves are dispensable for two distinct forms of cerebellar learning.

Multiple lines of evidence presented here support the conclusion that the apparent effects of CB1 deletion on cerebellar learning arise as a secondary consequence of the hypoactivity of global CB1KOs, rather than through direct effects on cerebellar plasticity. First, eyeblink conditioning deficits in CB1KO mice were fully accounted for by differences in locomotor activity, across both animals and trials (Figure 1). Second, eyeblink conditioning in global CB1KOs was fully rescued by equalizing locomotor activity with a motorized treadmill (Figure 2). Third, systemic CB1-antagonists did not impair eyeblink conditioning on a motorized treadmill (Kishimoto and Kano, 2006; Steinmetz and Freeman, 2010; Steinmetz and Freeman, 2018). Fourth, CB1KOs were able to learn to walk more symmetrically in a cerebellum-dependent locomotor learning task (Figure 4). Finally, mice lacking CB1 receptors in cerebellar granule cells exhibited none of the behavioral phenotypes observed in global knockouts.

Knockout animals have been used extensively to investigate the role of specific receptors and signaling pathways in complex behaviors such as learning and memory (Crawley 2008; Dubnau and Tully 1998; Picciotto and Wickman 1998). The sometimes-conflicting findings from this approach are often attributed to its widely-acknowledged drawbacks, including limited cellular and temporal specificity, and the possibility of compensatory mechanisms (El-Brolosy and Stainier 2017). In this case, we present a different confound: a receptor that appears to be required for learning in one behavioral context, is not required in another. Altering behavioral state - whether via the cannabinoid system, or by exposure to a motorized treadmill - profoundly modulates the capacity for learning. As a consequence, externally controlling locomotor activity rescues the effect of $\mathrm{CB} 1$ receptor deletion, revealing a complex interplay between genes, behavior, and learning (Eisener-Dorman, Lawrence, and Bolivar 2009; El-Brolosy and Stainier 2017; Picciotto and Wickman 1998; Crawley 2008).

Surprisingly, when we corrected for differences in locomotor activity, we often observed a small but consistent enhancement of learning in CB1KOs. This was true on the self-paced treadmill (Figure 1E,F) as well as on the motorized treadmill (Figure $2 \mathrm{~A}, \mathrm{C}$ ). This could be due to compensatory mechanisms upregulated in response to parallel fiber $\mathrm{CB} 1$ deletion, although interestingly, a similar trend was also observed following treatment with a CB1R antagonist (Figure 2B,C). An alternative possibility is that this small enhancement is a consequence of decreased arousal (Figure 1 - figure supplement 1D; Albergaria et al., 2018). Although locomotor activity levels generally increase with heightened arousal, as measured by pupil size (Vinck et al., 2015; Mineault et al., 2016; Reimer et al., 2014; Reimer et al., 2016), by controlling for differences in locomotion we previously demonstrated that increased arousal on its own has a small negative influence on learning (Albergaria et al., 2018). Thus the subtle enhancement of learning and the smaller pupil sizes in CB1KO mice (Figure 1 - figure supplement 1) are consistent with the possibility that the altered behavioral state of the CB1KOs could have two competing effects on learning: one detrimental, due to decreased locomotor activity, and one beneficial, due to decreased arousal. Under physiological conditions, however, the enhancement by locomotor activity is a much stronger determinant of learning (Albergaria et al., 2018). 
The modulation of behavioral state in CB1KO mice is likely to be of extra-cerebellar origin. Deletion of $\mathrm{CB} 1$ receptors from interneurons in the ventral tegmental area was identified as the source of hypoactivity in CB1KO mice (Dubreucq et al., 2013). CB1KOs also exhibit a number of other behavioral differences, including altered feeding and anxiety levels (Zimmer et al. 1999; Degroot and Nomikos 2004; Ravinet Trillou et al. 2004). It is possible that CB1Rs on non-granule cell types within the cerebellum, such as molecular layer interneurons or climbing fibers (Kreitzer et al., 2001b; Diana and Marty, 2004) may contribute either to hypoactivity and/or to the subtle motor phenotype we observed in mice walking on a motorized treadmill (Movie 2, Figure 4 - figure supplement 3). However, regardless of the origin of the hypoactivity, correcting for it reveals that CB1Rs are not required for eyeblink conditioning.

The finding that all behavioral measures were normal in G6KOs suggests that all forms of parallel fibermediated CB1-dependent plasticity at synapses onto either Purkinje cells or interneurons (Kreitzer and Regehr, 2001a; Brown et al., 2003; Brenowitz and Regehr, 2005; Safo and Regehr 2005; Soler-Llavina et al., 2006; Carey et al., 2011) are dispensable for eyeblink conditioning as well as cerebellumdependent locomotor coordination and learning. This seems unlikely to be solely due to compensation in the knockouts, since a CB1 antagonist, which induces hypoactivity, similarly caused no impairment in eyeblink conditioning on a motorized treadmill.

In pointing towards an extracerebellar role for CB1 receptors in modulating cerebellar learning, our results are consistent with previous findings that systemic CB1 antagonists impair eyeblink conditioning (Kishimoto and Kano, 2006; Steinmetz and Freeman, 2010), but localized infusion in the cerebellar cortex does not (Steinmetz and Freeman, 2020). While both systemic (Steinmetz and Freeman 2016) and intracerebellar (Steinmetz and Freeman 2020) CB1 agonists impair acquisition, this is likely to be due to acute suppression of neurotransmitter release, rather than reflecting specific effects on learning. Indeed, our results suggest that endocannabinoid signaling within the cerebellar cortex may be less important for learning-related plasticity than for regulating overall levels of excitability and transmission (Marsicano et al., 2003; Regehr et al., 2009).

Since previous studies have demonstrated the necessity of CB1 receptors in parallel fiber LTD (Safo and Regehr 2005; Carey et al., 2011), our results would seem to argue against a critical role for parallel fiber LTD in cerebellar learning. While we cannot rule out the possibility that a CB1-independent form of LTD could be invoked in vivo, there are a host of other plasticity mechanisms within the cerebellar circuit that could provide potential substrates for learning (Hansel et al., 2001; Carey 2011; Gao et al. 2012; Johansson et al., 2015). However, we emphasize that a broader point made by our results is that such reductionist approaches to the complex system that is the brain of a behaving animal should be taken with caution. Myriad plasticity mechanisms can be induced in vitro, and variations in induction protocols and other factors may alter the specific cellular pathways involved under various conditions.

Neuromodulators like cannabinoids have multiple effects on synaptic transmission, plasticity, and behavioral state, and as we underscore here, untangling these effectively requires more than one approach.

In conclusion, CB1 receptors modulate cerebellum-dependent associative learning via indirect effects on behavioral state, and not via CB1-mediated parallel fiber plasticity. A large body of recent work has demonstrated profound effects of behavioral state, including locomotor activity and arousal, on brain function (Niell and Stryker 2010; Bennett, Arroyo, and Hestrin 2013; Ayaz et al. 2013; Polack, Friedman, and Golshani 2013; Erisken et al. 2014; Vinck et al. 2015; Pinto et al. 2013; Hardcastle et al., 2017; Musall et al., 2019; Stringer et al., 2019) and capacity for learning (Albergaria et al. 2018). Our findings extend these previous studies to establish alterations in behavioral state as a powerful, independent way that individual genes can contribute to complex behaviors such as learning and memory. 
bioRxiv preprint doi: https://doi.org/10.1101/511113; this version posted September 27, 2020. The copyright holder for this preprint (which was not certified by peer review) is the author/funder, who has granted bioRxiv a license to display the preprint in perpetuity. It is made available under aCC-BY-NC 4.0 International license.

\title{
Figure Legends
}

\author{
Figure 1. Correcting for differences in locomotor activity accounts for apparent deficits in eyeblink \\ conditioning
}

A. Setup for eyeblink conditioning in head-fixed mice on a running wheel, showing an LED as the CS and an air puff US. B. Sagittal sections showing the complete elimination of CB1R (red) in CB1KOs and DAPI staining the granule cell layer (blue). Images of the cerebellum of a representative control (upper panel) and global CB1 knockout (bottom panel). C. Average \%CR learning curves of global CB1 knockout mice (CB1KO, red, $\mathrm{N}=11$ ) and their littermate controls (WT, black, $\mathrm{N}=12$ ). Error bars indicate SEM. D. Average running distance of WT (black, $\mathrm{N}=12$ ) and $\mathrm{CB} 1 \mathrm{KO}$ (red, $\mathrm{N}=11$ ) on a self-paced treadmill across all learning sessions. Global CB1 knockout mice were significantly hypoactive ( ${ }^{*} p=0.015$ ). Box indicates median and 25th-75th percentiles, whiskers extend to the most extreme data points. E. Onset session of learning for CB1KO (red) and littermate controls (black), divided into top and bottom runners (open and filled circles, respectively), plotted against the animals' mean walking distance, averaged across all 20 training sessions. Vertical dashed line indicates the threshold used for dividing the control animals (150 meters/session, on average). Onset session was defined as the session in which the average CR amplitude exceeded 0.1. Each dot represents an animal. Lines are linear robust fits for CB1KO (red, slope $=-0.05,{ }^{*} p=0.02$ ) and controls (gray, slope $=-0.04,{ }^{\star} p=0.03$ ). F. Average of \%CR learning curves of CB1KO (red line, $\mathrm{N}=11$ ) compared with wildtype littermates with comparable (solid black line, $\mathrm{N}=6$ ) or increased locomotor activity levels (dashed black line, $\mathrm{N}=6$ ). Error bars indicate SEM. G. Average eyelid traces of CS-only trials from the last two training sessions for $\mathrm{CB} 1 \mathrm{KO}$ (red line, $\mathrm{N}=11$ ), hypoactive wildtype animals (solid black line, $\mathrm{N}=6$ ) and littermate controls with increased locomotor activity (dashed black line, $\mathrm{N}=6$ ). Vertical dashed line represents the time that the US would have been expected on CS+US trials. Shadows indicate SEM. H. Trial-to-trial correlation between eyelid response amplitude and walking speed. Amplitudes for all trials from 6 training sessions following learning onset (defined as in (E)) are plotted with lines representing averages across control (black) and global knockout (red) animals; shadows indicate SEM. There was a linear positive relationship for both controls $(N=12, F(1,65.9)=34.7$, $\left.{ }^{\star * *} \mathrm{p}=1.5 \mathrm{e}-07\right)$ and global knockouts $\left(\mathrm{N}=11, \mathrm{~F}(1,43.5)=43.4{ }^{* * *} \mathrm{p}=4.9 \mathrm{e}-08\right)$. Histograms indicate the relative $\%$ of trials (averaged across animals) from each genotype that fell in each speed bin. I. Average amplitude learning curves including only stationary trials of control (WT, black, $\mathrm{N}=12$ ) and $\mathrm{CB} 1 \mathrm{KO}$ mice (red, $\mathrm{N}=11$ ), aligned for each animal's onset session (defined as in (E)). Error bars indicate SEM. J. Average eyelid traces of stationary $(<0.05 \mathrm{~m} / \mathrm{s})$ CSonly trials for control (black) and CB1KO (red) animals, from same sessions in (I). Shadows indicate SEM. Vertical dashed line represents the time that the US would have been expected on CS+US trials. K. Mean eyelid amplitudes from stationary trials from same sessions as in (I). There was no significant difference in the average amplitude of control (black, $\mathrm{N}=12)$ vs. $\mathrm{CB} 1 \mathrm{KO}$ (red, $\mathrm{N}=11$ ) animals $(\mathrm{p}=0.58)$. Dots represent individual animals. Box indicates median and 25th-75th percentiles, whiskers extend to the most extreme data points.

\section{Figure 1 - figure supplement 1. Various measures of altered behavioral state in CB1KO mice and relationship to learning.}

A. Average distance run on the treadmill in each training session for each genotype, superimposed). B - E. Global CB1 knockout animals (red, $N=11$ ) walk overall more slowly than littermate controls (black, $N=12$ ), $B,{ }^{*} p=0.013$ ), spend on average less time walking during the sessions $\left(\mathbf{C},{ }^{\star *} p=0.002\right)$, have on average across all sessions, a smaller proportion of trials spent walking $\left(\mathbf{D},{ }^{* *} p=0.007\right)$ and have overall smaller pupils than controls $\left(\mathbf{E},{ }^{* *} p=\right.$ 0.008). In all boxplots (B - E), dots represent individual animals. Box indicates median and 25th-75th percentiles, whiskers extend to the most extreme data points. F. Count of wildtype (top, black) and CB1KO (bottom, red) animals by average distance walked across all 20 training sessions ( $25 \mathrm{~m}$ bins). Dashed gray lines indicate the threshold used in $(G)$ to separate more active from less active animals. G. Averaged learning curves of more (dashed lines) and less (solid lines) active animals, divided according to (F). For both controls (left plot, black, N=6+6) and CB1KO (right plot, red, $\mathrm{N}=6+5$ ), more active animals show faster learning. Error bars indicate SEM. H. Session-to-session changes in average CR amplitude (y-axis) of controls (black) and CB1KO (red) are plotted as a function of sessionto-session changes in walked distance (x-axis), for all training sessions following learning onset, color-coded for session number (darker colors correspond to earlier sessions and lighter colors correspond to later sessions). In both genotypes, changes in $\mathrm{CR}$ amplitude were positively correlated with changes in locomotor activity (controls: slope = $0.0005,{ }^{* *} p=9.87 e-08$; CB1KO: slope $\left.=0.0006,{ }^{* * *} p=9.93 e-05\right)$. I - L. Onset sessions of learning (as defined in Fig. $1 \mathrm{E})$ for each animal are plotted CB1KOagainst the animals' total walking distance (I), animals' average walking speed $(\mathbf{J})$, animals' average percentage of trials spent walking $(\mathbf{K})$ and animals' average percent time spent walking (L). Each dot represents an animal.

\section{Figure 1 - figure supplement 2. Learned response timing and short term, single-trial learning are normal in} global CB1KO mice.

A. Average conditioned responses for $\mathrm{CB} 1 \mathrm{KO}$ (red, $\mathrm{N}=8$ ) and littermate controls (black, $\mathrm{N}=8$ ) trained to a $500 \mathrm{~ms}$ CS-US interstimulus interval. Data are from CS-only trials from two test sessions $(50 \%$ of the trials are CS-only, randomly interleaved with CS-US trials) following acquisition. Vertical dashed line represents the time that the US would have been expected on CS+US trials. Shadows indicate SEM. B. Average peak times of conditioned responses from control (black) and CB1 knockout (red) mice trained to a $300 \mathrm{~ms}$ or a $500 \mathrm{~ms}$ ISI. Horizontal dashed lines indicate the time of the US in each condition. There was no significant difference in the average peak timing of conditioned responses of controls and CB1KO mice for either interval (300ms ISI: $p=0.12 ; 500 \mathrm{~ms} \mathrm{ISI:} p=0.24$ ). 
bioRxiv preprint doi: https://doi.org/10.1101/511113; this version posted September 27, 2020. The copyright holder for this preprint (which was not certified by peer review) is the author/funder, who has granted bioRxiv a license to display the preprint in perpetuity. It is made available under aCC-BY-NC 4.0 International license.

Dots represent individual animals. Box indicates median and 25th-75th percentiles, whiskers extend to the most extreme data points. C-D. Comparison of CR amplitudes on trials during test sessions that were preceded by trials with (CS-US) or without (CS-only) an air puff US. C. Averaged eyelid traces from trials that were preceded by a trial with an air puff US (solid line) or by a CS-only trial (dashed line), for control (black, left plot) and CB1KO (red, right plot) mice. Vertical dashed line represents the time of the US (present on $50 \%$ of trials). Shadows indicate SEM. D. Average peak amplitude of responses from trials preceded by a trial with or without an air puff US. CRs are larger following a CS-US trial in both genotypes (controls: black, paired t-test, ${ }^{* \star *} \mathrm{p}=3.6 \mathrm{e}-05$; CB1KO: red, paired t-test, ${ }^{\star *} p=0.002$ ). Thin lines are individual animals and thick lines correspond to averages for each genotype.

Figure 2. Equalizing locomotor activity with a motorized treadmill rescues $C B 1$-related learning deficits A. Average \%CR learning curves of global CB1 knockout (red, $\mathrm{N}=6$ ) mice and littermate controls (black, $\mathrm{N}=6$ ), while running at a fixed speed $(0.12 \mathrm{~m} / \mathrm{s})$ on a motorized treadmill. Error bars indicate SEM. B. Average \%CR learning curves of mice injected with vehicle solution (black, $N=12$ ) or with the CB1R antagonist AM251 (red, $N=13$ ), while running at a fixed speed $(0.12 \mathrm{~m} / \mathrm{s})$. Error bars indicate SEM. C. Average onset session of learning for animals in (A), wildtype (WT) and CB1KO mice (top two boxplots) and in (B), mice injected with vehicle or with AM251 (bottom two boxplots). There was no significant difference in learning onset session between WT and CB1KO $(p=0.64)$. Average onset session between animals injected with vehicle or the antagonist AM251 was marginally different ( $p=$ 0.05). Dots represent individual animals. Box indicates median and 25th-75th percentiles, whiskers extend to the most extreme data points. D. Average conditioned response eyelid traces of CS-only trials from all training sessions of control (black) and CB1 global knockout (red) animals. Shadows indicate SEM. Vertical dashed line represents the time that the US would have been expected on CS+US trials. E. Average conditioned response eyelid traces of CSonly trials from all training sessions of mice injected with vehicle (black) or AM251 (red). Shadows indicate SEM. Gray vertical line represents time of airpuff US. F. Mean CR amplitudes from all training sessions of each experimental group: controls, CB1KO, animals injected with vehicle and animals injected with AM251 (from left to right). There was no significant difference in the average amplitude of WT and CB1KO mice ( $p=0.82$, first two boxplots) or in mice injected with vehicle or AM251 ( $p=0.32$, last two boxplots). Dots represent individual animals. Box indicates median and 25th-75th percentiles, whiskers extend to the most extreme data points.

Figure 2 - figure supplement 1. CB1R antagonist AM251 causes hypoactivity, both across groups and within animals.

A - D. Animals were injected with AM251 $(\mathrm{N}=9)$ or with vehicle $(\mathrm{N}=9)$ and different parameters were measured $30 \mathrm{~min}$ post-injection, while the animals were head-fixed, but could walk on the self-paced treadmill, for a total of 5 sessions of $\sim 20 \mathrm{~min}$. Compared to animals injected with vehicle, mice injected with AM251 walk overall less $(\mathbf{A}, p=$ 0.05), more slowly $(B, p=0.05)$, spend less time walking $\left(\mathbf{C},{ }^{*} p=0.003\right)$ and have smaller average pupil size (D, ${ }^{*} p$ $=0.004)$. In all boxplots $(\mathbf{A}-\mathbf{D})$, dots represent individual animals. Box indicates median and 25th-75th percentiles, whiskers extend to the most extreme data points. $\mathbf{E}-\mathbf{G}$. Animals were injected with vehicle and their locomotor activity was recorded on the self-paced treadmill. The same animals were tested on the following day, post-injection of AM251, and comparisons within animals were performed using a Student's paired t-test. Administration of CB1R antagonist $A M 251$ resulted in decreased locomotor activity $\left(\mathbf{E},{ }^{*} \mathrm{p}=0.009\right)$, slower speeds $\left(\mathbf{F},{ }^{*} \mathrm{p}=0.008\right)$ and less time spent walking $\left(\mathbf{G},{ }^{*} \mathrm{p}=0.01\right)$.

\section{Figure 2 - figure supplement 2. Vehicle (DMSO) solution drives hypoactivity in mice, preventing them from learning on the self-paced treadmill.}

A. Average \%CR learning curves of mice injected with AM251 $(\mathrm{N}=9)$ or with vehicle $(\mathrm{N}=9)$ 30min before each training session on the self-paced treadmill, for a total of 10 sessions. Thin lines correspond to individual animals. B. Average running distance of WT $(\mathrm{N}=12)$, CB1KO $(\mathrm{N}=11)$, WT mice injected with vehicle $(\mathrm{N}=9)$, or with $\mathrm{AM} 251(\mathrm{~N}=9)$ on a self-paced treadmill across 10 learning sessions. DMSO-containing vehicle alone caused hypoactivity $(p=0.0077)$.

\section{Figure 3. Eyeblink conditioning is intact in granule cell-specific CB1 knockout mice}

A. Sagittal sections showing the selective elimination of CB1R (red) from cerebellar granule cells in G6KO and DAPI staining the granule cell layer (blue). Images of the cerebellum of a representative control (upper panel) and granulecell conditional CB1 knockout (bottom panel). B. Average running distance of G6KO (cyan, $\mathrm{N}=8$ ) mice and their littermate controls ( $\mathrm{G} 6 \mathrm{CTL}$, blue, $\mathrm{N}=9$ ) and on a self-paced treadmill across 20 learning sessions. The difference in average distance between groups was not significant $(p=0.704)$. Box indicates median and 25th-75th percentiles, whiskers extend to the most extreme data points. C. Average \%CR learning curves of granule cell-specific CB1 knockout mice (G6KO, cyan, $\mathrm{N}=8$ ) and littermate controls ( $\mathrm{G} 6 \mathrm{CTL}$, blue, $\mathrm{N}=9$ ), walking on the self-paced treadmill. Error bars indicate SEM. D. Average conditioned response traces of CS-only trials from all training sessions on a self-paced treadmill for control (blue) and G6KO (cyan) animals. Shadows indicate SEM. Vertical dashed line represents the time that the US would have been expected on CS+US trials. E. Average \%CR learning curves of G6KO (cyan, $\mathrm{N}=7$ ) and $\mathrm{G} 6 \mathrm{CTL}$ (blue, $\mathrm{N}=6$ ), while running at a fixed speed $(0.12 \mathrm{~m} / \mathrm{s}$ ) on a motorized treadmill. Error bars indicate SEM. F. Average conditioned response eyelid traces of CS-only trials from all training sessions on a motorized treadmill of control (blue) and granule cell-selective CB1 knockout (cyan) animals, on the motorized 
bioRxiv preprint doi: https://doi.org/10.1101/511113; this version posted September 27, 2020. The copyright holder for this preprint (which was not certified by peer review) is the author/funder, who has granted bioRxiv a license to display the preprint in perpetuity. It is made available under aCC-BY-NC 4.0 International license.

treadmill. Shadows indicate SEM. Vertical dashed line represents the time that the US would have been expected on $\mathrm{CS}+\mathrm{US}$ trials. G. Mean conditioned response amplitudes from all training sessions. There was no significant difference in the average amplitude ( $p=0.75$ ) of G6CTL (blue) vs. G6KO (cyan) animals. Dots represent individual animals. Box indicates median and 25th-75th percentiles, whiskers extend to the most extreme data points.

Figure 3 - figure supplement 1. Several measures of behavioral state reveal no differences between granule cell-specific CB1 knockout mice and controls

Granule cell-specific CB1 knockout mice (blue, $\mathrm{N}=9$ ) and their littermate controls (cyan, $\mathrm{N}=9$ ), show similar levels of average walking speed $(\mathbf{A}, p=0.70)$, percent time walking $(B, p=0.79)$, percentage of trials spent walking $(\mathbf{C}, p=0.78)$ and similar average pupil size $(\mathbf{D}, p=0.74)$, across all 20 training sessions. In all boxplots, dots represent individual animals. Box indicates median and 25th-75th percentiles, whiskers extend to the most extreme data points.

\section{Figure 4. Locomotor learning in global and granule cell-specific CB1 knockout mice}

A. Experimental protocol for split-belt locomotor adaptation. Mice underwent adaptation protocols consisting of baseline, split-belt (adaptation) and washout phases. Belt speeds were equal ('tied') in baseline trials and were then abruptly split (2:1 speed ratio) for the adaptation phase, before returning to the original, symmetrical tied-belt speed in the washout phase. B. The intra-limb parameter 'stride length' is the total forward motion of an individual limb from lift-off (swing) to touch-down (stance). C. Average front limb stride length asymmetry (fast-slow) over trials for global CB1 knockout mice (CB1 KO, $n=10$, red) and littermate controls (CB1 WT, $n=8$, black). Gray shaded patch indicates split-belt trials. Vertical gray bars indicate session breaks. D. Same as (C) for granule cell-specific CB1 knockout mice (G6KO, $n=8$, cyan) and their littermate controls (G6CTL, $n=6$, blue). E. The interlimb parameter 'step length' is how far forward one paw is relative to its contralateral pair at stance onset. F. Average front limb step length asymmetry (fast-slow) over trials for global CB1 knockout mice and littermate controls, plotted as in (B). G. Same as (F) for granule cell-specific CB1 knockout mice and their littermate controls. $\mathbf{H}$. Average step length aysmmetries at three key experimental phases: initial error during the first split-belt trial), the change in step length asymmetry over the split period (defined as the difference in step length asymmetries in the last minus the first splitbelt trial), and aftereffect (first trial upon returned to tied belt condition), +/- SEM, for global CB1KOs (red) and littermate controls (black). The signs of the changes over split and aftereffects have been inverted in order to allow direct comparison of magnitudes across the three epochs. Individual animals are shown with smaller, open circles. The change over the split-belt period and the aftereffects, which both reflect learned changes in step symmetry, are comparable in the two genotypes. I. Average changes in step symmetry (+/- SEM) are plotted as a percent of the average initial error, for global CB1KO mice and littermate controls. Line at $100 \%$ shows complete adaptation. There is no deficit in learning in the CB1KOs. J. Same as $(\mathrm{H})$ for granule cell-specific CB1 knockouts (cyan) and littermate controls (blue). Individual animals are shown with smaller, open circles. K. Same as (H) but for granule cell-specific CB1 knockouts and littermate controls.

\section{Figure 4 - figure supplement 1. Analysis of overground locomotion in global and granule cell-specific CB1KO mice.}

A. Mean (+/- SEM) individual limb parameters stride length (left), cadence (middle) and stance duration as a function of walking speed for global CB1KO mice $(\mathrm{N}=7)$ and their littermate controls $(\mathrm{N}=7)$. B. Average front limb paw trajectories during swing phases are plotted for forward $(x)$ instantaneous velocity (left), side-to-side (y) movements relative to the body (center), and vertical (z) position (right). Thicker lines indicate faster walking speeds. C. Measures of interlimb coordination. Left: Suppport patterns (the configuration of paws on the ground simultaneously) are typically dominated by 2-paw diagonal support configurations in mice. Here we plot the \% of irregular paw supports, in which 3 paws and 2 non-diagonal (other) paws provide support, as a function of walking speed. Center: Relative phasing of foot touch-down for each paw (color coded according to the inset), relative to the front, right reference limb (red). Thin lines and open circles represent CB1KO data. Rright: step length (as in Figure 4E). D-F: Same as $(A-C)$ but for granule cell specific $C B 1 K O$ mice $(N=4$; cyan) and their littermate controls ( $N=6$; black/grey). See Methods and (Machado et al., 2015; Machado et al., 2020) for detailed gait parameter descriptions.

\section{Figure 4 - figure supplement 2. Linear discriminant analysis separates CB1KO mice from two mutants with cerebellar ataxia}

A. Linear discriminant analysis (LDA) of locomotor parameters separates mutants with cerebellar ataxia (pcd and reeler) from global and cell-specific CB1KO and size-matched controls. For this analysis, we included 45 gait parameters describing the movement of individual limbs, interlimb coordination, body trajectories and variability (see Methods). Each dot represents the average over all analyzed strides of a single animal walking at a particular speed $(0.2-0.25 \mathrm{~m} / \mathrm{s})$. Size and speed-matched controls for all groups are shown in black $(\mathrm{N}=15)$, global CB1KO mice in red $(N=7)$, granule cell-specific CB1 knockout mice $(G 6 K O)$ in cyan $(n=4)$, reeler in green $(N=8)$ and pcd mutants in purple $(\mathrm{N}=3)$. Bars underneath and next to the main axes represent the contribution scores (LD coefficients) of each locomotor parameter. B. Magnitude of differences (Cohen's d) compared to size-matched controls for gait parameters included in LDA across genotypes ( $p c d$, reeler, G6KO and CB1KO). Black dots indicate significant differences (unpaired t-test). Mice with cerebellar ataxia show sig. differences variability, interlimb and body coordination (Machado, Darmohray et. al., 2015; Machado et.al., 2020). Global CB1KO mice showed sig. 
bioRxiv preprint doi: https://doi.org/10.1101/511113; this version posted September 27, 2020. The copyright holder for this preprint (which was not certified by peer review) is the author/funder, who has granted bioRxiv a license to display the preprint in perpetuity. It is made available under aCC-BY-NC 4.0 International license.

differences in \% stance hind, diagonal phase and CV coo front. No significant differences were observed between G6KO and controls in any gait parameter included.

Figure 4 - figure supplement 3. Analysis of treadmill locomotion in global and granule cell-specific CB1KO mice

A. Mean (+/- SEM) individual limb parameters stride length (left), cadence (middle) and stance duration as a function of walking speed for global CB1KOs ( $\mathrm{N}=12$; red) and their littermate controls ( $\mathrm{N}=8$; black/grey). B. Average front limb paw trajectories during swing phases are plotted for forward ( $\mathrm{x}$ ) instantaneous velocity (left), side-to-side (y) movements relative to the body (center), and vertical $(z)$ position (right). Thicker lines indicate faster walking speeds. C. Interlimb coordination. \% of irregular paw supports (3 paws and 2 paw non-diagonal (other)), as a function of walking speed. Center: Relative phasing of foot touch-down for each paw (color coded according to the inset), relative to the front, right reference limb (red). Thin lines and open circles represent CB1KO data. Rright: step length (as in Figure 4E). D-F: Same as A-C but for granule cell specific CB1KO mice ( $N=8$; cyan) and their littermate controls ( $\mathrm{N}=6$; black/grey). See method for detailed gait parameter descriptions. 
bioRxiv preprint doi: https://doi.org/10.1101/511113; this version posted September 27, 2020. The copyright holder for this preprint (which was not certified by peer review) is the author/funder, who has granted bioRxiv a license to display the preprint in perpetuity. It is made available under aCC-BY-NC 4.0 International license.

\section{Methods}

\section{Animals}

All procedures were carried out in accordance with the European Union Directive 86/609/EEC and approved by the Champalimaud Centre for the Unknown Ethics Committee and the Portuguese Direcção Geral de Veterinária (Ref. No. 0421/000/000/2015). Mice were kept on a reversed 12-h light/12-h dark cycle, in standard cages with typically 24 animals per cage. They had access to food and water ad libitum. All procedures were performed in male and female mice approximately 10-14 weeks of age.

\section{Global and conditional knockouts}

Global CB1R knockout mice (Cnr1 -/-, here termed CB1KO) (Zimmer et al., 1999) and their littermate controls (Cnr1 $+/+$ ) were obtained by crossing heterozygous breeding pairs. Gabra6-Cre;Cnr1 flox/flox mice were generated by crossing mice (Gabra6-Cre) in which Cre recombinase expression was driven by the promoter of the alpha6 subunit of the GABAA receptor and was specific to granule cells within the cerebellar cortex (Fünfschilling and Reichardt 2002), with mice (Cnr1 flox/flox, (Marsicano et al., 2003) carrying floxed alleles of the Cnr1 gene that encodes the CB1R receptor. Gabra6-Cre;Cnr1 flox/flox mice have been previously characterized and shown to lack parallel fiber LTD, as well as CB1R-mediated short-term forms of parallel-fiber-Purkinje cell plasticity (Carey et al., 2011). All lines were kept in a C57BL/6-J background.

\section{Surgical procedures}

In all our surgeries, animals were anesthetized with isoflurane ( $4 \%$ induction and $0.5-1 \%$ for maintenance), placed in a stereotaxic frame (David Kopf Instruments, Tujunga, CA) and a custom-cut metal head plate was glued to the skull with dental cement (Super Bond - C\&B). After any surgical procedure, mice were monitored and allowed $\sim 1-2$ days of recovery.

\section{Drugs}

Mice were injected intra-peritoneally with AM251 (A6226, Sigma; 3mg/kg; Corbillé et al., 2007; Sousa et al., 2011; Xi et al., 2008) or vehicle, 30 minutes before each training session. AM251 was suspended in saline with $5 \%$ DMSO and $1 \%$ Tween 80 , at a concentration of $3 \mathrm{mg} / \mathrm{ml}$. Control mice were injected with vehicle consisting of saline with $5 \%$ DMSO and $1 \%$ Tween 80 . The vehicle alone reduced locomotor activity levels but did not impair ability of the mice to walk on the motorized treadmill (Figure 2 - figure supplement 2), and AM251 induced additional hypoactivity beyond the effects of vehicle (Figure 2 - figure supplement 1 ).

\section{Histology}

To confirm CB1R expression in the different mouse lines, animals were perfused transcardially with $4 \%$ paraformaldehyde and their brains removed. Sagittal sections (50um thick) were cut in a Cryostat and stained with a polyclonal guinea pig antibody raised against the last 31 amino acids of the CB1R C-terminal (from Frontier Institute co., Itd) and DAPI. Sections were mounted on glass slides with Vectashield ${ }^{\circledR}$ mounting medium and imaged with a 10x objective.

\section{Eyeblink conditioning}

The experimental setup was based on previous work (Albergaria et al., 2018; Chettih et al., 2011). For all behavioral experiments, mice were head-fixed but could walk freely on a Fast-Trac Activity Wheel (Bio-Serv) and habituated to the behavioral setup for at least 4 days prior to training. To externally control the speed of the treadmill, a DC motor with an encoder (Maxon) was used. For experiments on the motorized treadmill, mice were additionally habituated to walk at the target speed until they walked normally and displayed no external signs of distress. There was no difference across genotypes in the amount of habituation time.

Locomotor activity was measured using an infra-red reflective sensor placed underneath the treadmill. Eyelid movements of the right eye were recorded using a high-speed monochromatic camera (Genie HM640, Dalsa) to monitor a $172 \times 160$ pixel region, at $900 f$ ps. Custom-written software using LabVIEW, together with a NI PCIE-8235 frame grabber and a NI-DAQmx board (National Instruments), was used to trigger and control all the hardware in a synchronized manner.

Acquisition sessions consisted of the presentation of 100 CS-US paired trials and 10 CS-only trials, which allow for the analysis of the kinematics of CRs without the masking effect that comes from the US-elicited reflex blink. The 110 trials were separated by a randomized inter trial interval (ITI) of 5-20s. In each trial, CS and US onsets were separated by a fixed interval (ISI) of $300 \mathrm{~ms}$ and both stimuli co-terminated. The experiments in Figure 1 - figure supplement 2 were conducted in dedicated 'test sessions' following acquisition, in which only $50 \%$ of the trials contained an air puff US, in order to assess the influence of US presence/ absence on single-trial learning.

For all training experiments, the unconditioned stimulus (US) was an air-puff (40psi, 50ms) controlled by a Picospritzer (Parker) and delivered via a $27 \mathrm{G}$ needle positioned $\sim 0.5 \mathrm{~cm}$ away from the cornea of the right eye of the mouse. The direction of the air-puff was adjusted for each session of each mouse so that the unconditioned stimulus 
bioRxiv preprint doi: https://doi.org/10.1101/511113; this version posted September 27, 2020. The copyright holder for this preprint (which was not certified by peer review) is the author/funder, who has granted bioRxiv a license to display the preprint in perpetuity. It is made available under aCC-BY-NC 4.0 International license.

elicited a normal eye blink. The CS had a 350ms duration and was a white light LED $(5 \mathrm{~mW})$ positioned $\sim 3 \mathrm{~cm}$ directly in front of the mouse.

The video from each trial was analyzed offline with custom-written software using MATLAB (MathWorks). The distance between eyelids was calculated frame by frame by thresholding the grayscale image and extracting the minor axis of the ellipse that delineated the eye. Eyelid traces were normalized for each session, ranging from 1 (full blink) to 0 (eye fully open). Trials were classified as CRs if the eyelid closure reached at least 0.1 (in normalized pixel values) and occurred between 100ms after the time of CS onset and the onset of US.

\section{Analysis of locomotor coordination}

Locomotor coordination was assessed using our previously described LocoMouse setup, a tracking and analysis system for freely moving mice (Machado et al., 2015). Briefly, mice walked across a glass corridor, with a mirror placed at 45 deg below the mouse, so that a single high-speed camera recorded both bottom and side views. Individual trials consisted of single crossings of the corridor. Mice initiated trials by walking back and forth between two dark 'home' boxes on each end of the corridor. Tracking and gait analysis was performed offline.

Tracking data was first broken down into strides using a simple peak detection algorithm (Machado et al., 2015). For the analyses shown in Figure 4 - figure supplement 2, we computed a range of locomotor parameters to compare global CB1KO mice to Purkinje cell degeneration $(p c d)$ and reeler mutants with cerebellar atrophy and consequent ataxia (Lalonde and Strazielle, 2007; Mullen et al., 1976; Falconer 1951; Machado et al., 2015; Machado et al., 2020). We included 45 gait parameters describing the movement of individual limbs, interlimb coordination, body trajectories and variability. The reported gait parameters have been previously described (Machado et al., 2015; Machado et al., 2020). Gait parameter descriptions were computed as follows:

\section{Individual limb parameters}

Individual limb parameters for both front right (FR) and hind right (HR) paws were included in all analyses.

Stride duration: time between two consecutive stance onsets

Cadence: inverse of stride duration

Swing velocity: $x$ displacement of single limb during swing phase divided by the swing duration

Stride length: $x$ displacement from touchdown to touchdown of single limb

Duty factor: stance duration divided by stride duration

Trajectories: $(x, y, z)$ trajectories were aligned to swing onset and resampled to 100 equidistant points using linear interpolation. Interpolated trajectories were then binned by speed and the average trajectory was computed for each individual animal and smoothed with a Savitzky-Golay first-order filter with a 3-point window size.

Instantaneous swing velocity: the derivative of swing trajectory.

Variability: All variability analyses were based on coefficients of variation (CV).

\section{Interlimb and whole-body coordination parameters}

Base of support: width between the two front and two hind paws during stance phase

Stance phase: relative timing of limb touchdowns to stride cycle of reference paw (FR). Calculated as: stance time stance timereference paw /stride duration. We report stance phase as left-right (LR) and front-hind (FH) phase.

Supports: Support types were categorized by how many and which paws were on the ground, expressed as a percentage of the total stride duration for each stride. Paw support categories include 3-paw, 2-paw diagonal, 2-paw other/ non-diagonal (homolateral and homologous).

Double support: for each limb is defined as the percentage of the stride cycle between the touch down of a reference paw to lift-off of the contralateral paw.

Center of oscillation: midpoint between swing and stance $\mathrm{x}$ positions relative to body center.

Step length: displacement of one limb relative to its contralateral homolog at stance onset.

For linear discriminant analysis (LDA, Figure 4 - figure supplement 2A), each observation was data from one mouse locomoting at a specific speed and features are z-scored gait parameters. Since, LDA assumes independence within the feature space, PCA was applied first to address inter-variable correlation and avoid overfitting. PCA was performed by eigenvalue decomposition of the data covariance matrix. The first 10 PCs explained $86 \%$ of the variance and the data projected onto these 10 PCs was used as input to the LDA. The end contributions of the initial gait parameters to the two LD axes were obtained by multiplying the PCA mapping by the LDA mapping.

\section{Locomotor learning on a split-belt treadmill}

Split-belt locomotor adaptation experiments and analyses were performed on a modified version of the LocoMouse setup (Machado et al., 2015) as previously described (Darmohray et al., 2019). Two motor-driven transparent treadmill belts independently imposed the walking speed on the two sides of the body. Split-belt locomotor adaptation experiments consisted of 'baseline' tied, split-belt, and 'washout' tied belt trials. All trials were one minute in duration, with brief periods in which the motors were off, in between trials. 
bioRxiv preprint doi: https://doi.org/10.1101/511113; this version posted September 27, 2020. The copyright holder for this preprint (which was not certified by peer review) is the author/funder, who has granted bioRxiv a license to display the preprint in perpetuity. It is made available under aCC-BY-NC 4.0 International license.

Granule-cell specific CB1KO mice and their littermate controls were run in a single session adaptation protocol (2 tied trials, 8 split trials; 8 tied trials). For these mice, split-belt trial speeds were at a 2.14:1 ratio: $0.175 \mathrm{~m} / \mathrm{s}$ (slow) and $0.375 \mathrm{~m} / \mathrm{s}$ (fast). Global CB1KO mice and their littermate controls underwent a longer, multi-session adaptation protocol consisting of 10 trials per day (session 1: 3 tied, 7 split; sessions 2-3: 10 split; session 4: 3 split, 7 tied; session 5: 10 tied), with lower overall belt speeds (tied: $0.2 \mathrm{~m} / \mathrm{s}$; slow: $0.125 \mathrm{~m} / \mathrm{s}$ fast: $0.275 \mathrm{~m} / \mathrm{s}$ ).

For split-belt locomotor adaptation analyses (Figure 4), we compared mutants and littermate controls on individual and interlimb coordination parameters. For individual limb analyses, we compared the two groups on their initial response to split-belt walking by assessing how stride length and step length symmetry scaled on the first split-belt trials. Limb speeds during stance were monitored throughout the splitbelt period to ensure that animals were consistently maintaining split belt walking; two animals were excluded from the global CB1KO experiment for not meeting this criterion. To assess learned changes in interlimb coordination, we compared the change in symmetry from early to late split (late - early) and aftereffects (first washout trial - average baseline) of mutants and littermate controls. For percent symmetry change plots, changeover split trials (late - early) and aftereffects were normalized by the average (group) initial error.

\section{Statistics}

Statistical analyses were performed using the Statistics toolbox in MATLAB and R. For the correlation between speed and CR amplitude (Figure $1 \mathrm{H}$ ), we used a mixed model approach. We specified random slopes and intercepts models and included mouse/subject as a random covariate using the Ime2 package (Bates, 2005). We report $F$ tests (ANOVA) with Satterthwaite degrees of freedom correction; reported post-hoc analyses are t-tests with Tukey corrections for multiple comparisons. For the correlation between average distance and onset session (Figure 1E), as well as session-to-session changes in distance and CR amplitude (Figure 1 - figure supplement $1 \mathrm{H}$ ), we used linear regression. To compare the average distance between animals of each genotype (Figure 1D; Figure 3B), the differences between average CR peak amplitudes (Figure 1 - figure supplement $2 B$ ), onset learning sessions (Figure 2C) and the average amplitudes of eyelid closure (Figure 1K; Figure 2F; Figure 3G), we used Student's unpaired t-tests. For comparing behavioral state parameters between CB1KOs and littermate controls (Figure 1 figure supplement $1 B-E$ ), as well as between animals injected with AM251 or vehicle solution (Figure $2-$ figure supplement $1 A-D$ ) and granule-cell specific CB1KOs and respective controls (Figure 3 - figure supplement $1 \mathrm{~A}-$ $D$ ), we used the same test. For within animal comparisons (Figure 2 - figure supplement $1 E-G$, Figure 1 - figure supplement 2D), we performed a Student's paired t-test.

For locomotor adaptation analyses, we used mixed models to test for fixed effects of genotype (CB1KOs and littermate controls) and experimental phase on the asymmetry of each gait parameter (either stride length, step length). Experimental phase had three levels including early split (initial error), change over split trials (late - early) and aftereffects. Early and late split were the first and last split belt trials. Aftereffects were the first post-split tied belt trial. We specified random slopes and intercepts models and included mouse/subject as a random covariate using the Ime4 package (Bates, 2005). Reported statistics are post-hoc $t$-tests with Tukey corrections for multiple comparisons and were conducted using the Ismeans package in R (Lenth, 2016). All statistical comparisons are conducted on animal averages (i.e., each animal has one observation per level(s) of the independent variable).

All t-tests were two-tailed. Differences were considered significant at ${ }^{*} p<0.05,{ }^{* *} p<0.01$ and ${ }^{* * *} p<0.001$. No sample size calculation was performed, Although sample sizes were not pre-determined with sample size calculations, they were based on related previous research (Heiney et al. 2014; Albergaria et al., 2018; Darmohray et al. 2019), and statistical tests were run after data collection. Mice were assigned to specific experimental groups according to their genotype and without bias.

\section{Acknowledgements}

We thank Tracy Pritchett and Ana Vaz for maintenance of mouse lines. Sofia Araújo, Catarina Almeida, Sofia Cohen, and Teresa Duarte assisted with some experiments. We thank Wade Regehr and Rui Costa for support during the initial planning of this project. We are grateful to the members of Carey lab and the Champalimaud Neuroscience Program for helpful discussion.

This work was supported by a Howard Hughes Medical Institute International Early Career Scientist Grant \#55007413 (to MRC), a European Research Council Starting Grant \#640093 (to MRC), Congento LISBOA-01-0145-FEDER-022170, co-financed by FCT (Portugal) and Lisboa2020 under the PORTUGAL2020 agreement, and fellowships from the Portuguese Fundação para a Ciência e a Tecnologia SFRH/BD/77686/2011 (to CA), SFRH/BD/105949/2014 (to NTS), SFRH/BD/86265/2012 (to DD). 


\section{References}

Aiba, A., M. Kano, C. Chen, M. E. Stanton, G. D. Fox, K. Herrup, T. A. Zwingman, and S. Tonegawa. 1994. "Deficient Cerebellar Long-Term Depression and Impaired Motor Learning in mGluR1 Mutant Mice." Cell 79 (2): 377-88.

Albergaria, Catarina, N. Tatiana Silva, Dominique L. Pritchett, and Megan R. Carey. 2018. "Locomotor Activity Modulates Associative Learning in Mouse Cerebellum." Nature Neuroscience 21 (5): 725-35.

Albus, James S. 1971. "A Theory of Cerebellar Function.” Mathematical Biosciences 10 (1): 25-61.

Ayaz, Aslı, Aman B. Saleem, Marieke L. Schölvinck, and Matteo Carandini. 2013. "Locomotion Controls Spatial Integration in Mouse Visual Cortex." Current Biology 23 (10): 890-94.

Bennett, Corbett, Sergio Arroyo, and Shaul Hestrin. 2013. "Subthreshold Mechanisms Underlying State-Dependent Modulation of Visual Responses.” Neuron 80 (2): 350-57.

Bates, D. (2005). Fitting linear mixed models in R. R News, 5(1), 27-30.

Berghuis, P., Rajnicek, A. M., Morozov, Y. M., Ross, R. A., Mulder, J., Urbán, G. M., et al. 2007. Hardwiring the brain: endocannabinoids shape neuronal connectivity. Science. 316(5828): 1212-1216.

Bilkei-Gorzo. A., I. Racz, O. Valverde, M. Otto, K. Michel, M. Sarstre, and A. Zimmer. 2005. "Early age-related cognitive impairment in mice lacking cannabinoid CB1 receptors." PNAS 102 (43): 15670-15675.

Brenowitz, Stephan D., and Wade G. Regehr. 2005. "Associative Short-Term Synaptic Plasticity Mediated by Endocannabinoids." Neuron 45 (3): 419-31.

Brown, Solange P., Stephan D. Brenowitz, and Wade G. Regehr. 2003. "Brief Presynaptic Bursts Evoke SynapseSpecific Retrograde Inhibition Mediated by Endogenous Cannabinoids." Nature Neuroscience 6 (10): 1048-57.

Carey, Megan R. 2011. "Synaptic Mechanisms of Sensorimotor Learning in the Cerebellum." Current Opinion in Neurobiology 21 (4): 609-15.

Carey, Megan R., Michael H. Myoga, Kimberly R. McDaniels, Giovanni Marsicano, Beat Lutz, Ken Mackie, and Wade G. Regehr. 2011. "Presynaptic CB1 Receptors Regulate Synaptic Plasticity at Cerebellar Parallel Fiber Synapses." Journal of Neurophysiology 105 (2): 958-63.

Chaouloff, Francis, Sarah Dubreucq, Luigi Bellocchio, and Giovanni Marsicano. 2011. "Endocannabinoids and Motor Behavior: CB1 Receptors Also Control Running Activity." Physiology 26 (2): 76-77; author reply 78.

Chettih SN, McDougle SD, Ruffolo LI, Medina JF. Adaptive timing of motor output in the mouse: the role of movement oscillations in eyelid conditioning. Frontiers in integrative neuroscience. 2011 Nov 30;5:72.

Chevaleyre, Vivien, Kanji A. Takahashi, and Pablo E. Castillo. 2006. "Endocannabinoid-Mediated Synaptic Plasticity in the CNS." Annual Review of Neuroscience 29: 37-76.

Crawley, Jacqueline N. 2008. "Behavioral Phenotyping Strategies for Mutant Mice.” Neuron 57 (6): 809-18.

Darmohray, D., J. Jacobs, H. G. Marques, and M. R. Carey. 2019. "Spatial and Temporal Locomotor Learning in Mouse Cerebellum.” Neuron, 102: 217-231. DOI: 10.1016/j.neuron.2019.01.038.

Degroot, Aldemar, and George G. Nomikos. 2004. "Genetic Deletion and Pharmacological Blockade of CB1 Receptors Modulates Anxiety in the Shock-Probe Burying Test." Eur J Neurosci 20 (4): 1059-64.

De Zeeuw, C. I., C. Hansel, F. Bian, S. K. Koekkoek, A. M. van Alphen, D. J. Linden, and J. Oberdick. 1998. "Expression of a Protein Kinase C Inhibitor in Purkinje Cells Blocks Cerebellar LTD and Adaptation of the VestibuloOcular Reflex." Neuron 20 (3): 495-508.

Diana, M.A., and Marty, A., 2004. "Endocannabinoid-mediated short-term synaptic plasticity: depolarization-induced suppression of inhibition (DSI) and depolarization-induced suppression of excitation (DSE)." Br J Pharmacol. 142(1): 9-19.

Dubnau, J., and T. Tully. 1998. "Gene Discovery in Drosophila: New Insights for Learning and Memory." Annual Review of Neuroscience 21: 407-44.

Dubreucq, Sarah, Audrey Durand, Isabelle Matias, Giovanni Bénard, Elodie Richard, Edgar Soria-Gomez, Christelle Glangetas, et al. 2013. "Ventral Tegmental Area Cannabinoid Type-1 Receptors Control Voluntary Exercise Performance." Biological Psychiatry 73 (9): 895-903.

Dubreucq, Sarah, Muriel Koehl, Djoher N. Abrous, Giovanni Marsicano, and Francis Chaouloff. 2010. "CB1 Receptor Deficiency Decreases Wheel-Running Activity: Consequences on Emotional Behaviours and Hippocampal Neurogenesis." Experimental Neurology 224 (1): 106-13.

Eisener-Dorman, Amy F., David A. Lawrence, and Valerie J. Bolivar. 2009. "Cautionary Insights on Knockout Mouse 
Studies: The Gene or Not the Gene?" Brain, Behavior, and Immunity 23 (3): 318-24.

El-Brolosy, Mohamed A., and Didier Y. R. Stainier. 2017. "Genetic Compensation: A Phenomenon in Search of Mechanisms." PLoS Genetics 13 (7): e1006780.

Erisken, Sinem, Agne Vaiceliunaite, Ovidiu Jurjut, Matilde Fiorini, Steffen Katzner, and Laura Busse. 2014. "Effects of Locomotion Extend throughout the Mouse Early Visual System." Current Biology: CB 24 (24): 2899-2907.

Falconer, D. 1951. 'Two new mutants,'trembler'and 'reeler', with neurological actions in the house mouse (Mus musculus L.)." Journal of genetics 50: 192-205.

Freund, Tamas F., Istvan Katona, and Daniele Piomelli. 2003. "Role of Endogenous Cannabinoids in Synaptic Signaling." Physiological Reviews 83 (3): 1017-66.

Gao, Z., Van Beugen, B.J., and De Zeeuw. C.I. 2012. "Distributed synergistic plasticity and cerebellar learning." Nature Reviews Neuroscience 13 (9), 619-635

Hansel, C., D. J. Linden, and E. D’Angelo. 2001. "Beyond Parallel Fiber LTD: The Diversity of Synaptic and NonSynaptic Plasticity in the Cerebellum." Nature Neuroscience 4 (5): 467-75.

Hardcastle K, Maheswaranathan N, Ganguli S, Giocomo LM. 2017. "A Multiplexed, Heterogeneous, and Adaptive Code for Navigation in Medial Entorhinal Cortex." Neuron. 94(2):375-387.

Heiney, Shane A., Margot P. Wohl, Selmaan N. Chettih, Luis I. Ruffolo, and Javier F. Medina. 2014. "CerebellarDependent Expression of Motor Learning during Eyeblink Conditioning in Head-Fixed Mice." Journal of Neuroscience 34 (45): 14845-53.

Ito, M. 1972. "Neural Design of the Cerebellar Motor Control System." Brain Research 40 (1): 81-84.

Johansson, F., Carlsson, H.A.E., Rasmussen, A., Yeo, C.H., Hesslow, G., 2015. "Activation of a temporal memory in Purkinje cells by the mGluR7 receptor." Cell reports 13 (9): 1741-1746.

Johansson, F., Jirenhed, D.A., Rasmussen, A., Zucca, R., Hesslow, G. 2018. "Absence of parallel fibre to Purkinje cell LTD during eyeblink conditioning." Scientific reports 8 (1): 1-5.

Khilkevich A, Halverson HE, Canton-Josh JE, Mauk MD. Links between single-trial changes and learning rate in eyelid conditioning. The Cerebellum. 2016 Apr 1;15(2):112-21.

Kim, J. J., \& Thompson, R. F. (1997). "Cerebellar circuits and synaptic mechanisms involved in classical eyeblink conditioning." Trends Neurosci., 20 (4), 177-181.

Kishimoto, Yasushi, and Masanobu Kano. 2006. "Endogenous Cannabinoid Signaling through the CB1 Receptor Is Essential for Cerebellum-Dependent Discrete Motor Learning." J Neurosci 26 (34): 8829-37.

Koekkoek, S. K. E., H. C. Hulscher, B. R. Dortland, R. A. Hensbroek, Y. Elgersma, T. J. H. Ruigrok, and C. I. De Zeeuw. 2003. "Cerebellar LTD and Learning-Dependent Timing of Conditioned Eyelid Responses." Science 301 (5640): 1736-39.

Kreitzer, A. C., and W. G. Regehr. 2001a. "Retrograde Inhibition of Presynaptic Calcium Influx by Endogenous Cannabinoids at Excitatory Synapses onto Purkinje Cells." Neuron 29 (3): 717-27.

Kreitzer, A. C., and W. G. Regehr. 2001b. "Cerebellar Depolarization-Induced Suppression of Inhibition Is Mediated by Endogenous Cannabinoids." The Journal of Neuroscience: The Official Journal of the Society for Neuroscience 21 (20): RC174.

Lalonde, R., and C. Strazielle. 2007. "Spontaneous and Induced Mouse Mutations with Cerebellar Dysfunctions: Behavior and Neurochemistry." Brain Research 1140 (April): 51-74.

Lenth, R.V. (2016). Least-Squares Means: The R Package Ismeans. JSS Journal of Statistical Software 69.

Luchtenburg, F.J., Schaaf, M.J.M. \& Richardson, M.K. 2019. Functional characterization of the cannabinoid receptors 1 and 2 in zebrafish larvae using behavioral analysis. Psychopharmacology 236: 2049-2058.

Machado, Ana S., Dana M. Darmohray, João Fayad, Hugo G. Marques, and Megan R. Carey. 2015. "A Quantitative Framework for Whole-Body Coordination Reveals Specific Deficits in Freely Walking Ataxic Mice." eLife 2015; 4: e07892.

Machado, A. S., Marques, H. G., Duarte, D. F., Darmohray, D. M., \& Carey, M. R. 2020. Shared and specific signatures of locomotor ataxia in mutant mice. eLife 2020; 9: e55356.

Mackie, Ken. 2006. "Cannabinoid receptors as therapeutic targets.” Annu Rev Pharmacol Toxicol 46:101-122.

Mackie, Ken. 2007. “Understanding Cannabinoid Psychoactivity with Mouse Genetic Models.” PLoS Biol 5(10): e280.

Marsicano, Giovanni, Sharon Goodenough, Krisztina Monory, Heike Hermann, Matthias Eder, Astrid Cannich, Shahnaz C. Azad, et al. 2003. "CB1 Cannabinoid Receptors and on-Demand Defense against Excitotoxicity." Science 302 (5642): 84-88. 
Marsicano, Giovanni, Carsten T. Wotjak, Shahnaz C. Azad, Tiziana Bisogno, Gerhard Rammes, Maria Grazia Cascio, Heike Hermann, et al. 2002. "The Endogenous Cannabinoid System Controls Extinction of Aversive Memories." Nature 418 (6897): 530-34.

McCormick, D. A., and R. F. Thompson. 1984. "Cerebellum: Essential Involvement in the Classically Conditioned Eyelid Response." Science 223 (4633): 296-99.

McGinley, M. J., Vinck, M., Reimer, J., Batista-Brito, R., Zagha, E., Cadwell, C. R., et al. 2015. "Waking state: Rapid variations modulate neural and behavioral responses." Neuron 87 (6): 1143-1161.Mineault, P. J., Tring, E., Trachtenberg, J. T., \& Ringach, D. L. (2016). Enhanced spatial resolution during locomotion and heightened attention in mouse primary visual cortex. J. Neurosci., 36 (24), 6382-6392.

Medina JF, Lisberger SG. Links from complex spikes to local plasticity and motor learning in the cerebellum of awake-behaving monkeys. Nature neuroscience. 2008 Oct;11(10):1185-92.

Morton, Susanne M., and Amy J. Bastian. 2006. "Cerebellar Contributions to Locomotor Adaptations during Splitbelt Treadmill Walking." The Journal of Neuroscience: The Official Journal of the Society for Neuroscience 26 (36): 9107-16.

Mullen, R. J., E. M. Eicher, and R. L. Sidman. 1976. "Purkinje Cell Degeneration, a New Neurological Mutation in the Mouse." Proceedings of the National Academy of Sciences of the United States of America 73 (1): 208-12.

Musall, S., Kaufman, M.T., Juavinett, A.L. et al. 2019. "Single-trial neural dynamics are dominated by richly varied movements." Nat Neurosci 22: 1677-1686.

Najafi F, Medina JF. Bidirectional short-term plasticity during single-trial learning of cerebellar-driven eyelid movements in mice. Neurobiology of learning and memory. 2020 Apr 1;170:107097.

Niell, Cristopher M., and Michael P. Stryker. 2010. "Modulation of Visual Responses by Behavioral State in Mouse Visual Cortex." Neuron 65 (4): 472-79.

Oakes, M.D., Wen Jing Law, Tobias Clark, Bruce A. Bamber, and Richard Komuniecki. 2017. "Cannabinoids Activate Monoaminergic Signaling to Modulate Key C. elegans Behaviors.” J Neurosci. 37(11): 2859-2869.

Pakan, J. M., Lowe, S. C., Dylda, E., Keemink, S. W., Currie, S. P., Coutts, C. A., \& Rochefort, N. L. 2016. "Behavioral-state modulation of inhibition is context-dependent and cell type specific in mouse visual cortex." Elife, 5: e14985.

Pamplona, Fabrício Alano, and Reinaldo Naoto Takahashi. 2006. "WIN 55212-2 Impairs Contextual Fear Conditioning through the Activation of CB1 Cannabinoid Receptors." Neuroscience Letters 397 (1-2): 88-92.

Perrett SP, Ruiz BP, Mauk MD. Cerebellar cortex lesions disrupt learning-dependent timing of conditioned eyelid responses. J Neurosci. 1993 Apr;13(4):1708-18. doi: 10.1523/JNEUROSCI.13-04-01708.1993. PMID: 8463846; PMCID: PMC6576722.

Picciotto, M. R., and K. Wickman. 1998. "Using Knockout and Transgenic Mice to Study Neurophysiology and Behavior." Physiological Reviews 78 (4): 1131-63.

Pinto, Lucas, Michael J. Goard, Daniel Estandian, Min Xu, Alex C. Kwan, Seung-Hee Lee, Thomas C. Harrison, Guoping Feng, and Yang Dan. 2013. "Fast Modulation of Visual Perception by Basal Forebrain Cholinergic Neurons." Nature Neuroscience 16 (12): 1857-63.

Polack, Pierre-Olivier, Jonathan Friedman, and Peyman Golshani. 2013. "Cellular Mechanisms of Brain StateDependent Gain Modulation in Visual Cortex." Nature Neuroscience 16 (9): 1331-39.

Powell, K., Mathy, A., Duguid, I., \& Häusser, M. 2015. Synaptic representation of locomotion in single cerebellar granule cells. Elife 4: e07290.

Ravinet Trillou, C., Delgorge, C., Menet, C. et al. 2004. "CB1 cannabinoid receptor knockout in mice leads to leanness, resistance to diet-induced obesity and enhanced leptin sensitivity." Int J Obes 28: 640-648.

Raymond, J. L., \& Medina, J. F. 2018. Computational principles of supervised learning in the cerebellum. Annual review of neuroscience, 41: 233-253.

Regehr, Wade G., Megan R. Carey, and Aaron R. Best. 2009. "Activity-Dependent Regulation of Synapses by Retrograde Messengers." Neuron 63 (2): 154-70.

Reimer, J., Froudarakis, E., Cadwell, C. R., Yatsenko, D., Denfield, G. H., \& Tolias, A. S. 2014. Pupil fluctuations track fast switching of cortical states during quiet wakefulness. Neuron, 84 (2), 355-362.

Reimer, J., McGinley, M. J., Liu, Y., Rodenkirch, C., Wang, Q., Mc-Cormick, D. A., \& Tolias, A. S. 2016. Pupil fluctuations track rapid changes in adrenergic and cholinergic activity in cortex. Nat. Commun., 7 (1).

Safo, Patrick K., and Wade G. Regehr. 2005. "Endocannabinoids Control the Induction of Cerebellar LTD.” Neuron 48 (4): 647-59. 
bioRxiv preprint doi: https://doi.org/10.1101/511113; this version posted September 27, 2020. The copyright holder for this preprint (which was not certified by peer review) is the author/funder, who has granted bioRxiv a license to display the preprint in perpetuity. It is made available under aCC-BY-NC 4.0 International license.

Schneider, D. M., \& Mooney, R. 2015." Motor-related signals in the auditory system for listening and learning." Current opinion in neurobiology 33: 78-84.

Schonewille, Martijn, Zhenyu Gao, Henk-Jan Boele, Maria F. Vinueza Veloz, Wardell E. Amerika, Antonia A. M. Simek, Marcel T. De Jeu, et al. 2011. "Reevaluating the Role of LTD in Cerebellar Motor Learning." Neuron 70 (1): 43-50.

Soler-Llavina, Gilberto J., and Bernardo L. Sabatini. 2006. "Synapse-Specific Plasticity and Compartmentalized Signaling in Cerebellar Stellate Cells." Nature Neuroscience 9 (6): 798-806.

Sousa VC, Assaife-Lopes N, Ribeiro JA, Pratt JA, Brett RR, Sebastiao AM. Regulation of Hippocampal Cannabinoid CB 1 Receptor Actions by Adenosine A 1 Receptors and Chronic Caffeine Administration: Implications for the Effects of $\Delta$ 9-Tetrahydrocannabinol on Spatial Memory. Neuropsychopharmacology. 2011 Jan;36(2):472-87.

Steinmetz, Adam B., and John H. Freeman. 2010. "Central Cannabinoid Receptors Modulate Acquisition of Eyeblink Conditioning." Learning \& Memory 17 (11): 571-76.

Steinmetz AB, Freeman JH. Cannabinoid modulation of memory consolidation within the cerebellum. Neurobiology of learning and memory. 2016 Dec 1;136:228-35.

Steinmetz, A.B. and Freeman, J.H. 2020. "Cannabinoid agonist administration within the cerebellar cortex impairs motor learning." Neurobiol Learn Mem, 170: 106896.

Steiner H, Bonner TI, Zimmer AM, Kitai ST, Zimmer A. Altered gene expression in striatal projection neurons in CB1 cannabinoid receptor knockout mice. Proc Natl Acad Sci U S A. 1999;96(10):5786-5790.

Stringer, C., Pachitariu, M., Steinmetz, N., Reddy, C. B., Carandini, M., \& Harris, K. D. 2019. "Spontaneous behaviors drive multidimensional, brainwide activity." Science, 364(6437): eaav7893.

Valverde O., Karsak M., Zimmer A. 2005. "Analysis of the Endocannabinoid System by Using CB1 Cannabinoid Receptor Knockout Mice.” In: Pertwee R.G. (eds) Cannabinoids. Handbook of Experimental Pharmacology, vol 168.

Varvel, S. A., and Aron H. Lichtman. 2002. "Evaluation of CB1 Receptor Knockout Mice in the Morris Water Maze." The Journal of Pharmacology and Experimental Therapeutics 301 (3): 915-24.

Vinck, Martin, Renata Batista-Brito, Ulf Knoblich, and Jessica A. Cardin. 2015. "Arousal and Locomotion Make Distinct Contributions to Cortical Activity Patterns and Visual Encoding." Neuron 86 (3): 740-54.

Vinueza Veloz MF, Zhou K, Bosman LW, et al. 2015. "Cerebellar control of gait and interlimb coordination." Brain Struct Funct. 220(6):3513-3536.

Xi ZX, Spiller K, Pak AC, Gilbert J, Dillon C, Li X, Peng XQ, Gardner EL. Cannabinoid CB1 receptor antagonists attenuate cocaine's rewarding effects: experiments with self-administration and brain-stimulation reward in rats. Neuropsychopharmacology. 2008 Jun;33(7):1735-45.

Yanagihara, Dai, and Ikio Kondo. 1996. "Nitric Oxide Plays a Key Role in Adaptive Control of Locomotion in Cat." Proceedings of the National Academy of Sciences of the United States of America 93 (23): 13292-97.

Yang Y, Lisberger SG. Learning on multiple timescales in smooth pursuit eye movements. Journal of Neurophysiology. 2010 Nov;104(5):2850-62.

Zimmer, A., A. M. Zimmer, A. G. Hohmann, M. Herkenham, and T. I. Bonner. 1999. "Increased Mortality, Hypoactivity, and Hypoalgesia in Cannabinoid CB1 Receptor Knockout Mice." Proceedings of the National Academy of Sciences of the United States of America 96 (10): 5780-85. 

available under aCC-BY-NC 4.0 International license.

A

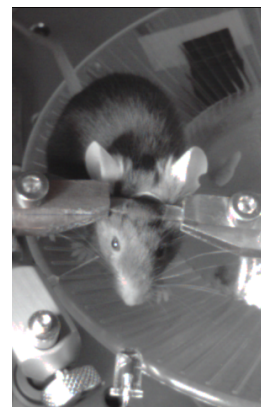

B

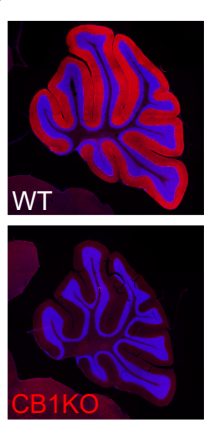

C

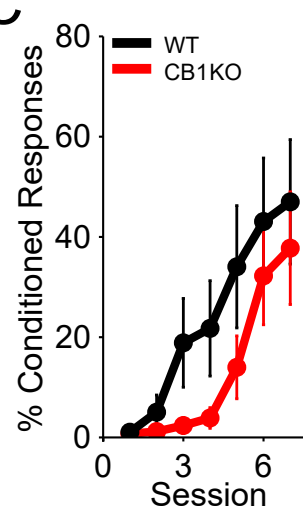

D

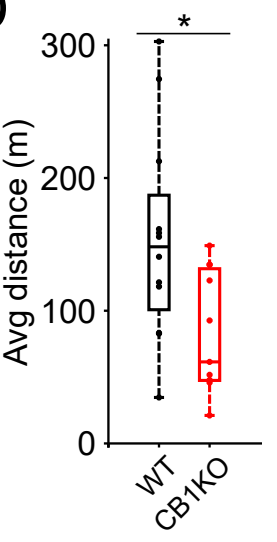

G

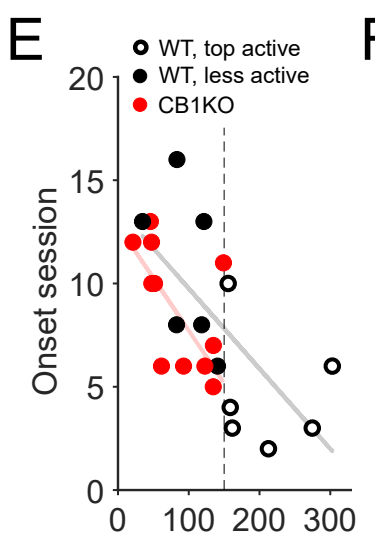

Avg distance/session (m)

$\mathrm{F}$

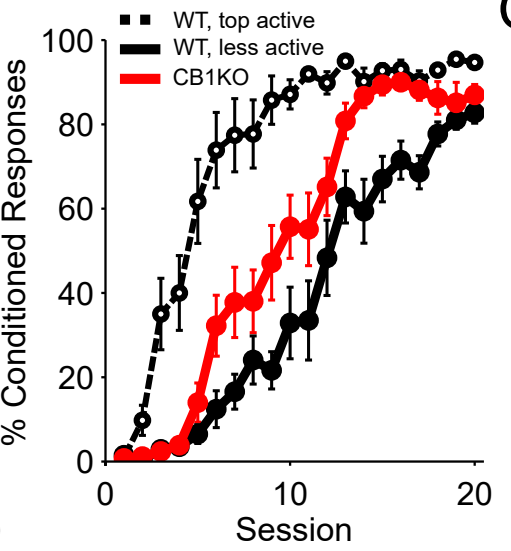

$\mathrm{J}$
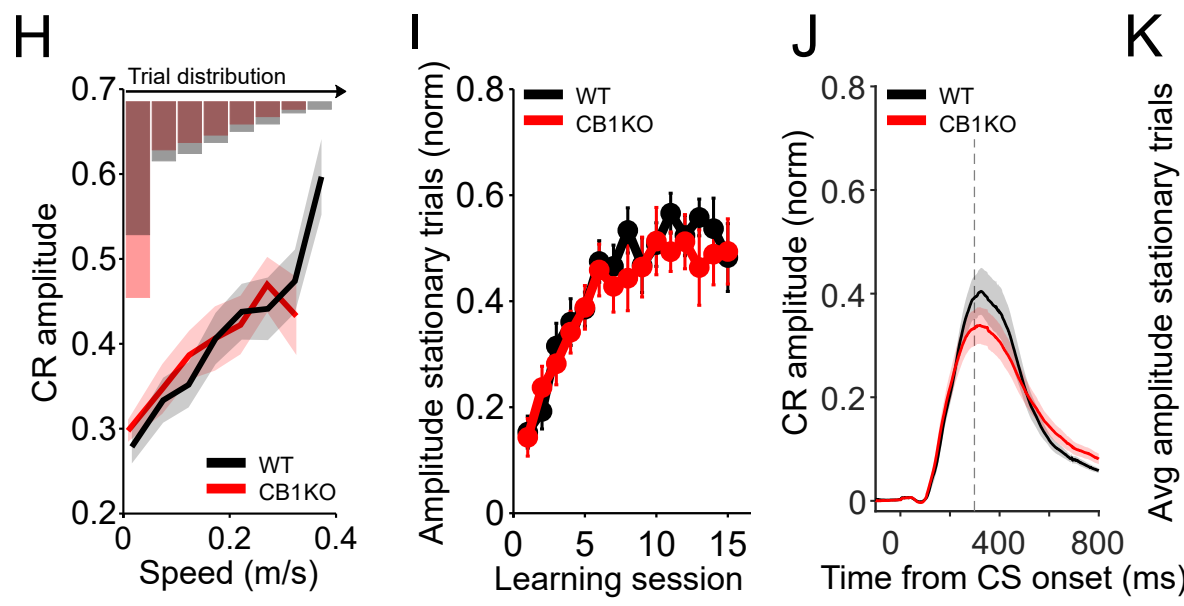

K

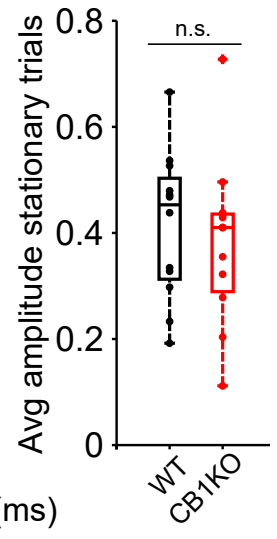


bioRxiv preprint doi: https://doi.org/10.1101/511113; this version posted September 27, 2020. The copyright holder for this preprint (which was not certified by peer review) is the author/funder, who has granted bioRxiv a license to display the preprint in perpetuity. It is made

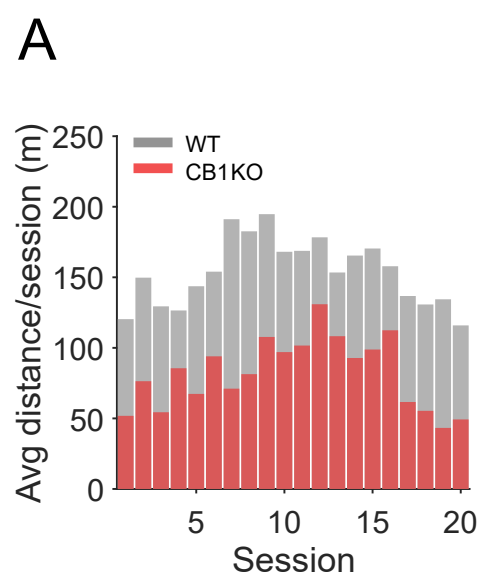
B
C
D $\quad E$
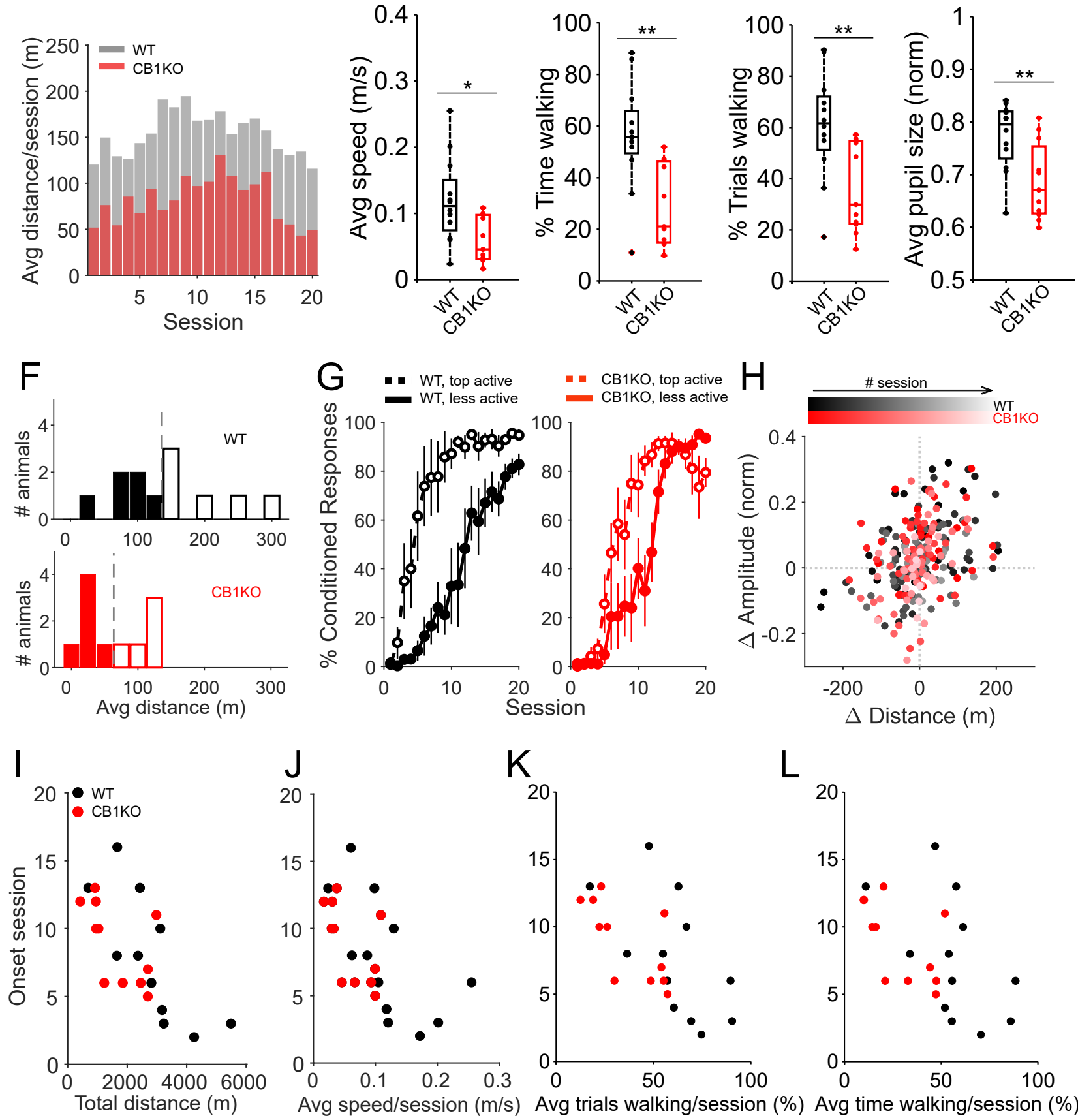

Avg speed/session (m/s) Avg trials walking/session (\%) Avg time walking/session (\%) 
A

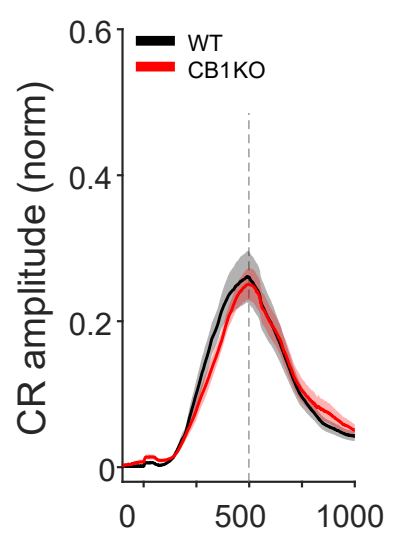

Time from CS onset (ms)
B

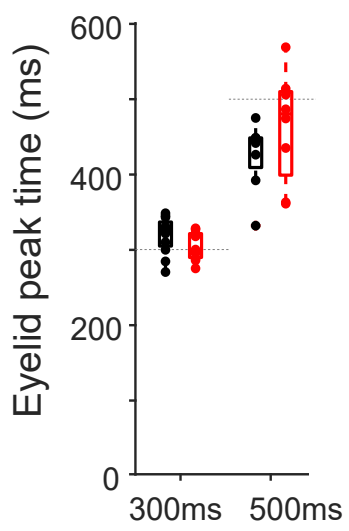

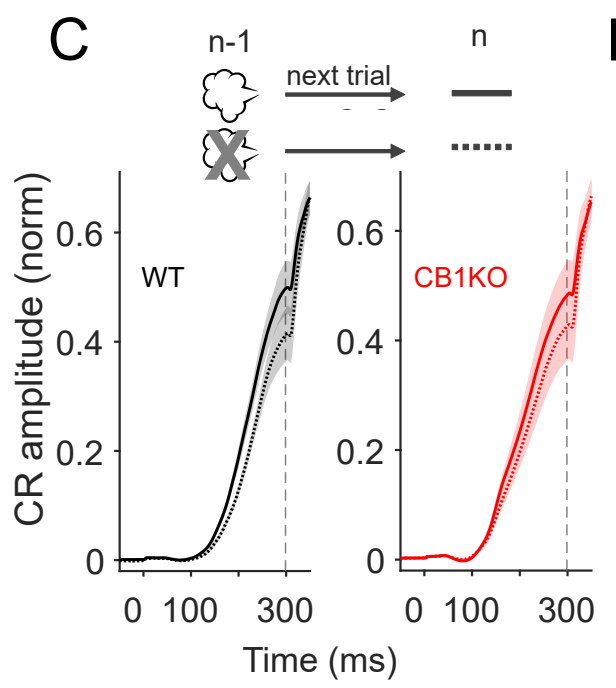

D

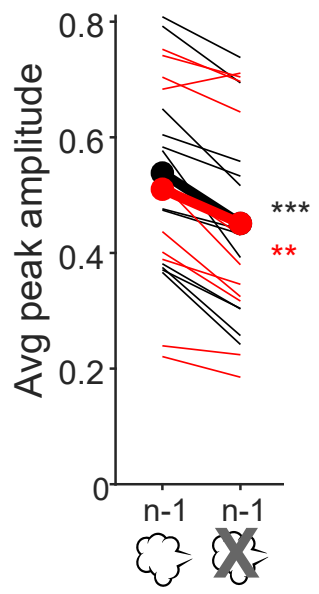


bioRxiv preprint dol: https://doi.org/10.1101/511113; this version posted September 27, 2020. The copyright holder for this preprint (which was not certified by peer review) is the author/funder, who has granted bioRxiv a license to display the preprint in perpetuity. It is made available under aCC-BY-NC 4.0 International license.

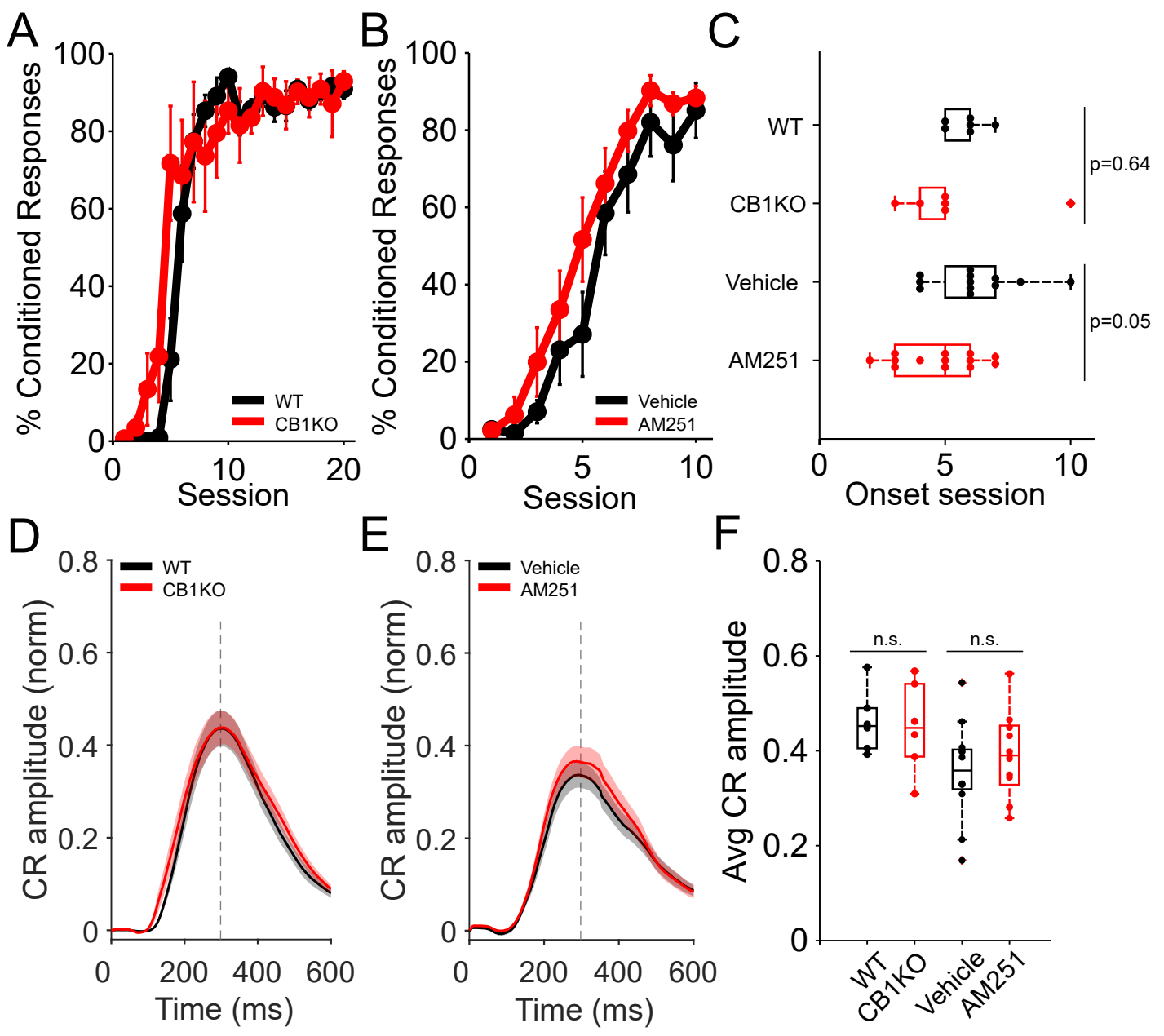



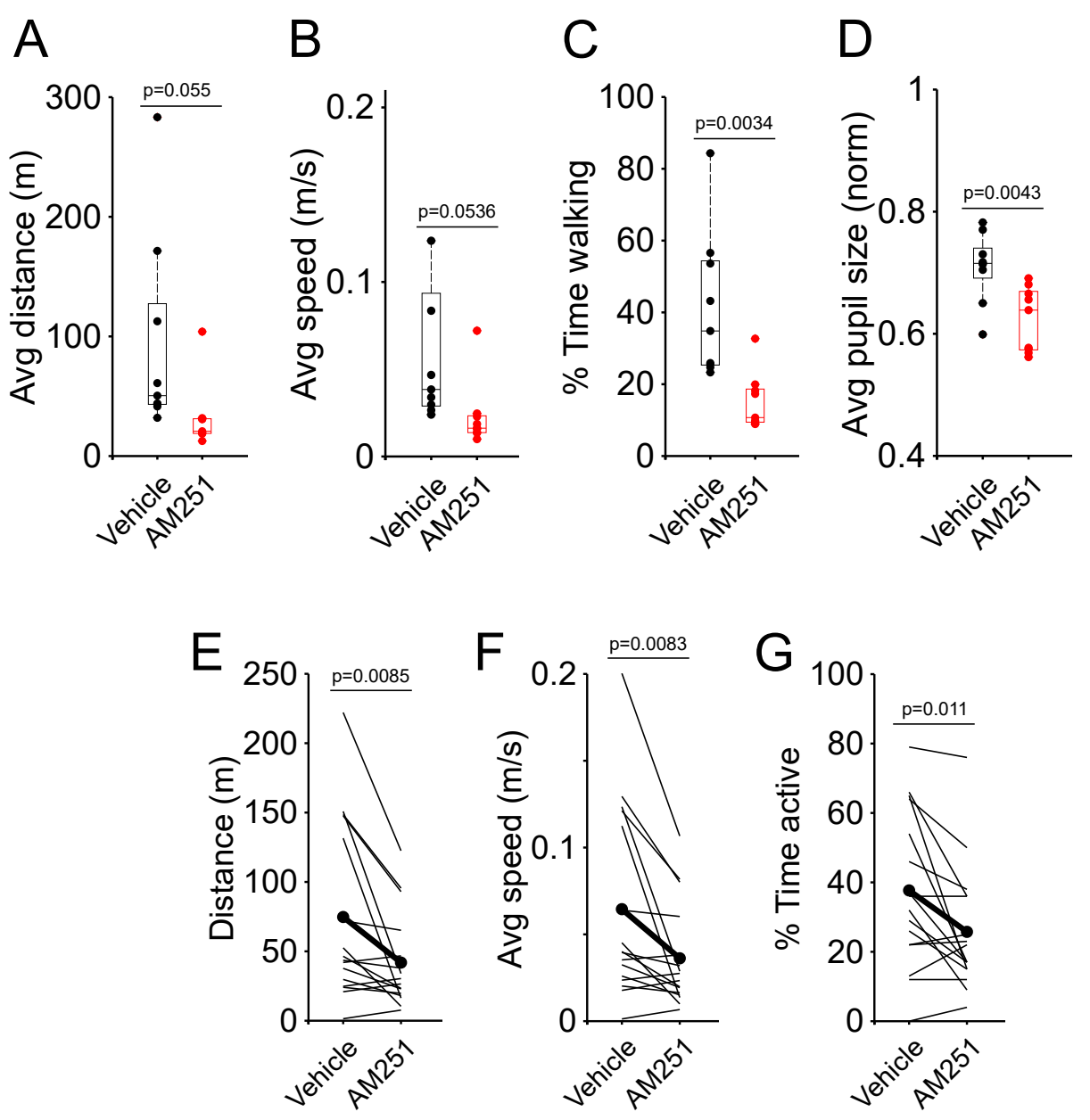
bioRxiv preprint doi: https://doi.org/10.1101/511113; this version posted September 27, 2020. The copyright holder for this preprint (which was not certified by peer review) is the author/funder, who has granted bioRxiv a license to display the preprint in perpetuity. It is made available under aCC-BY-NC 4.0 International license.
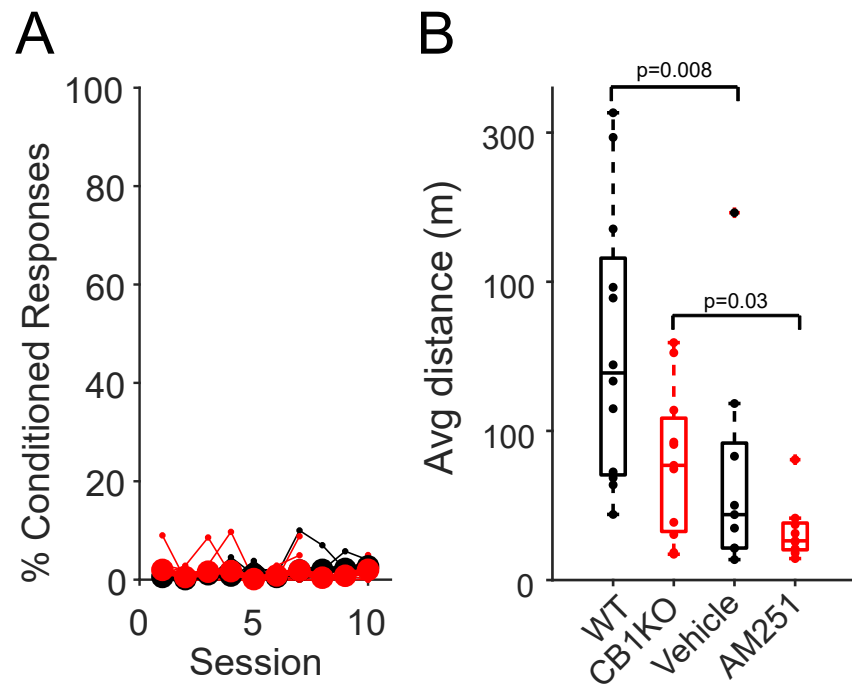
bioRxiv preprint doi: https://doi.org/10.1101/511113; this version posted September 27, 2020. The copyright holder for this preprint (which was not certified by peer review) is the author/funder, who has granted bioRxiv a license to display the preprint in perpetuity. It is made available under aCC-BY-NC 4.0 International license.
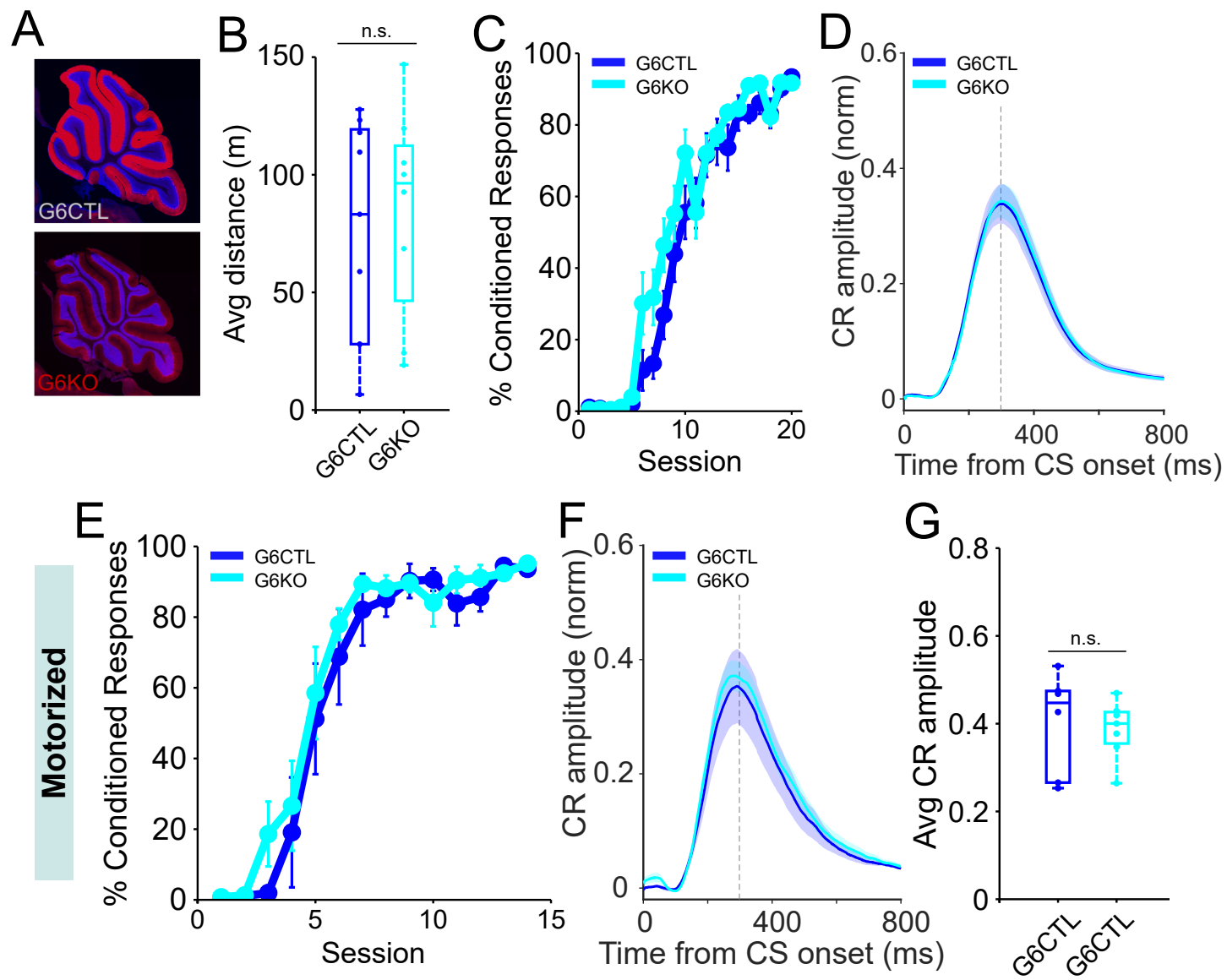
bioRxiv preprint doi: https://doi.org/10.1101/511113; this version posted September 27, 2020. The copyright holder for this preprint (which was not certified by peer review) is the author/funder, who has granted bioRxiv a license to display the preprint in perpetuity. It is made

A

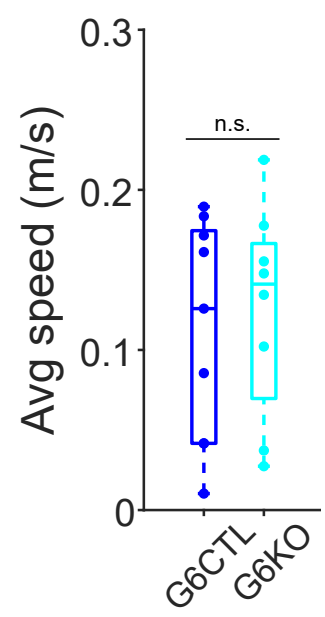

B

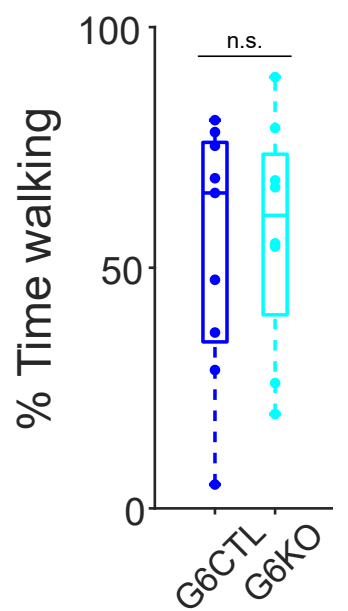

C

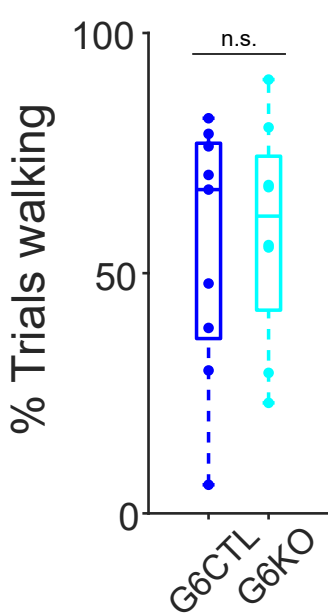

$\mathrm{D}$

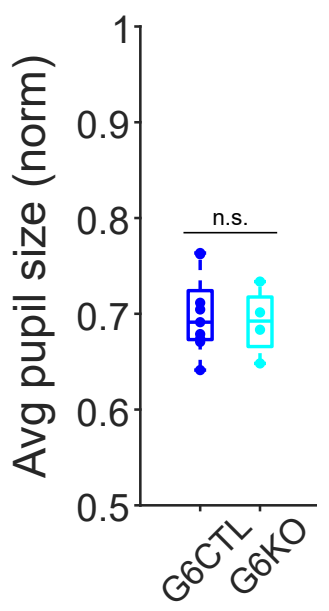


bioRxiv preprint doi: https://doi.org/10.1101/511113; this version posted September 27, 2020. The copyright holder for this preprint (which was not certified by peer review) is the author/funder, who has granted bioRxiv a license to display the preprint in perpetuity. It is made available under aCC-BY-NC 4.0 International license.

A

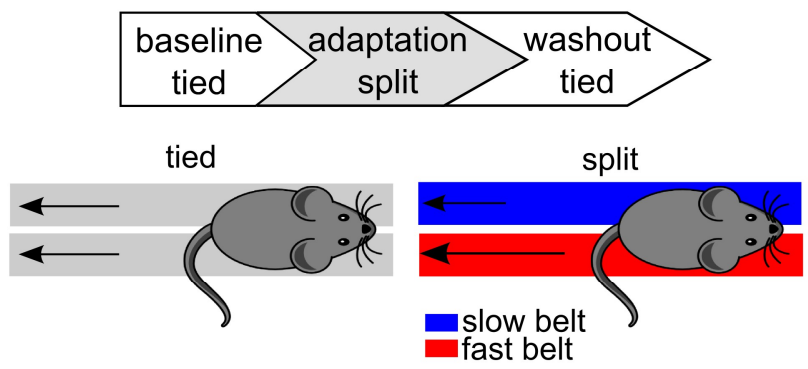

B

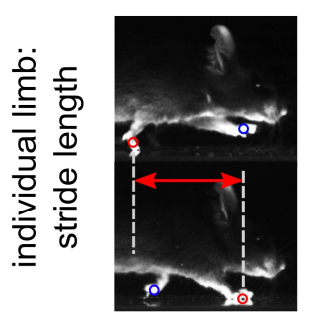

$\mathrm{E}$

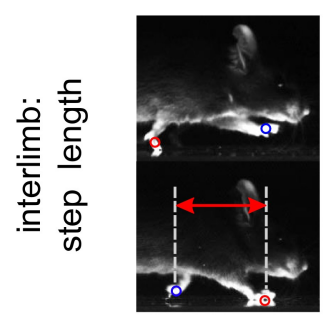

$\mathrm{H}$

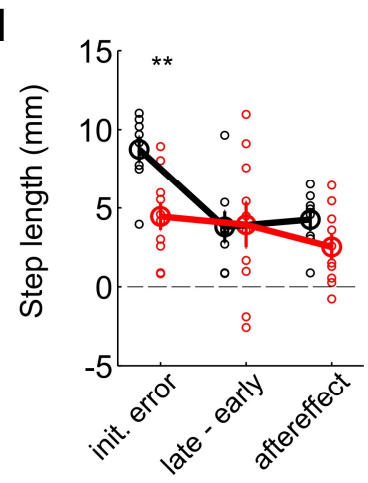

$\mathrm{C}$

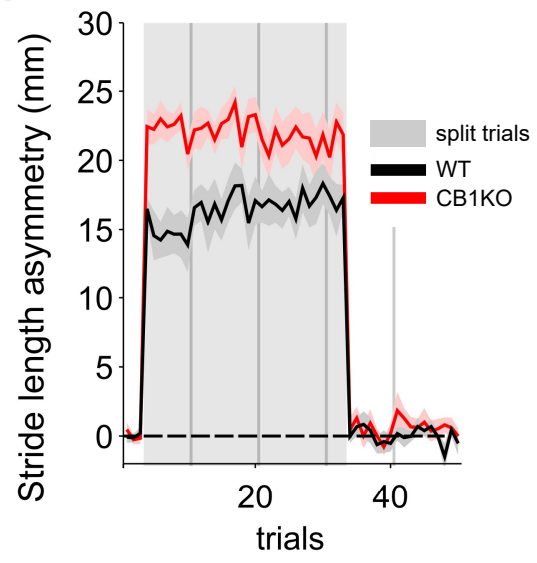

$\mathrm{F}$

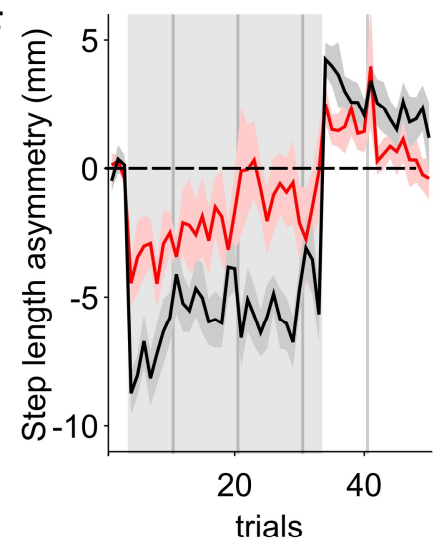

D
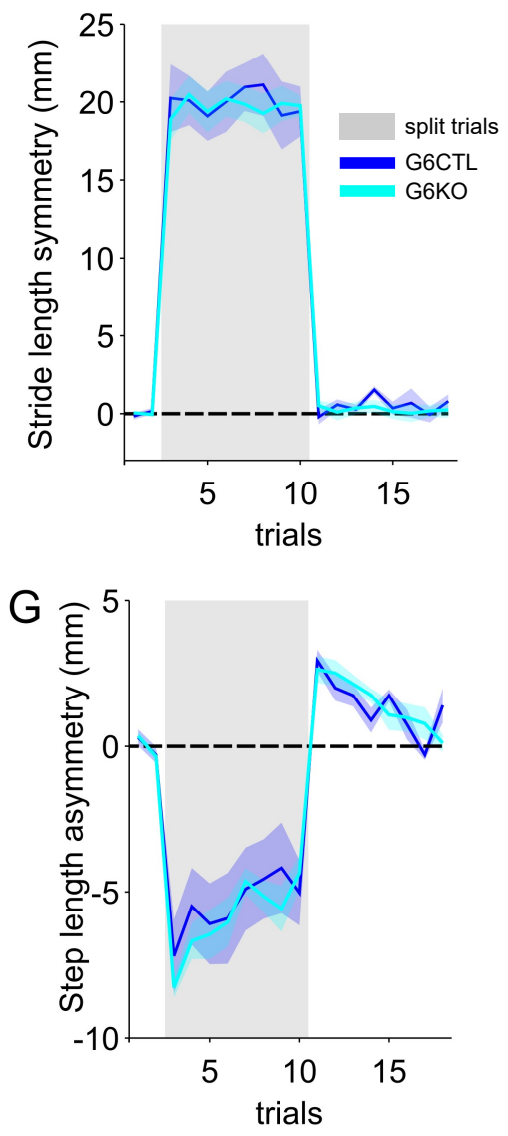

K

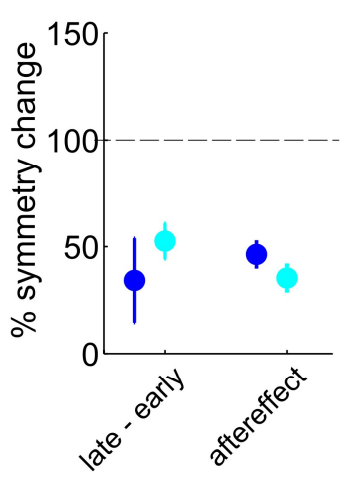


bioRxiv preprint doi: https://doi.org/10.1101/511113; this version posted September 27, 2020. The copyright holder for this preprint (which was not certified by peer review) is the author/funder, who has granted bioRxiv a license to display the preprint in perpetuity. It is made A available under aCC-B.3-NC 4.0 International license.

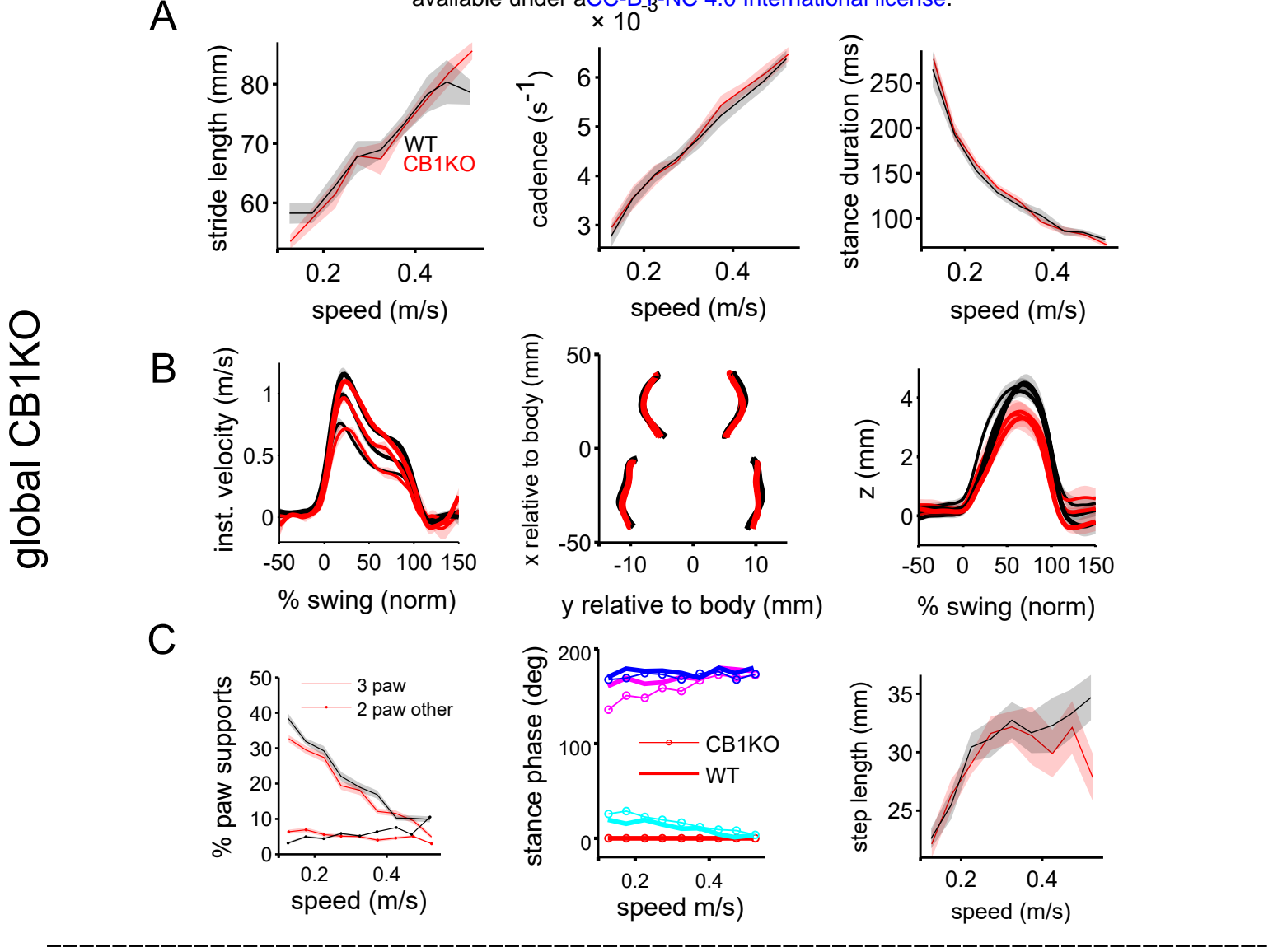

$\mathrm{D}$

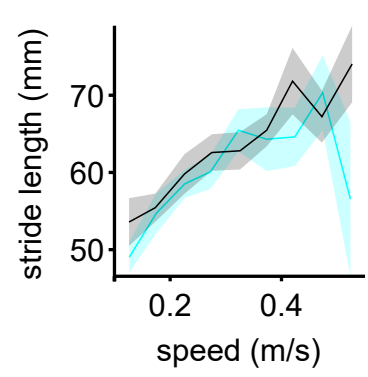

E

0

0
0
0
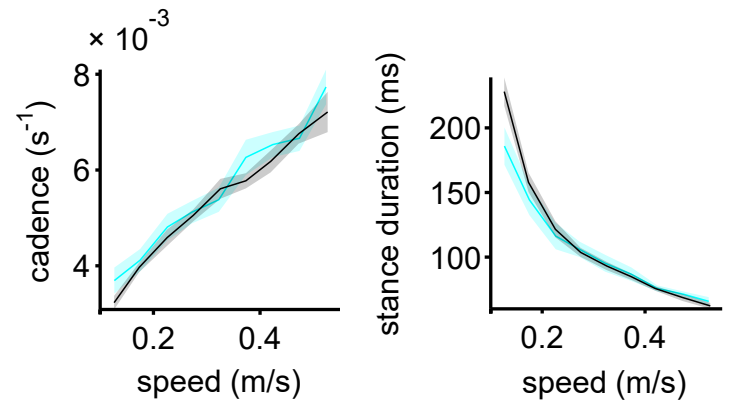

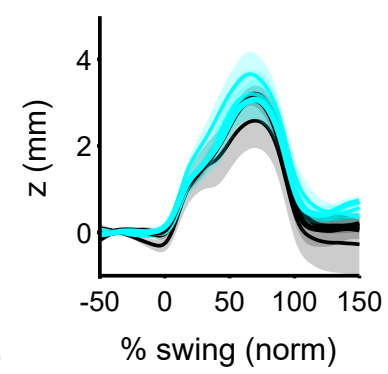

$\mathrm{F}$
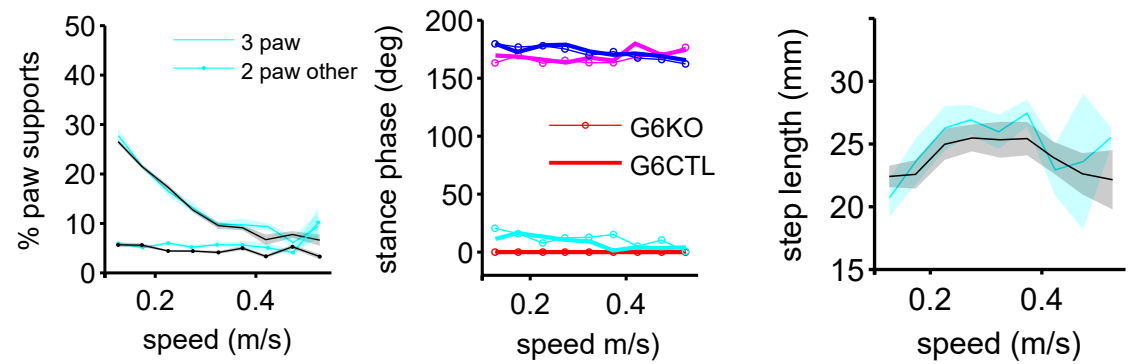
bioRxiv preprint doi: https://doi.org/10.1101/511113; this version posted September 27, 2020. The copyright holder for this preprint (which was not certified by peer review) is the author/funder, who has granted bioRxiv a license to display the preprint in perpetuity. It is made available under aCC-BY-NC 4.0 International license.

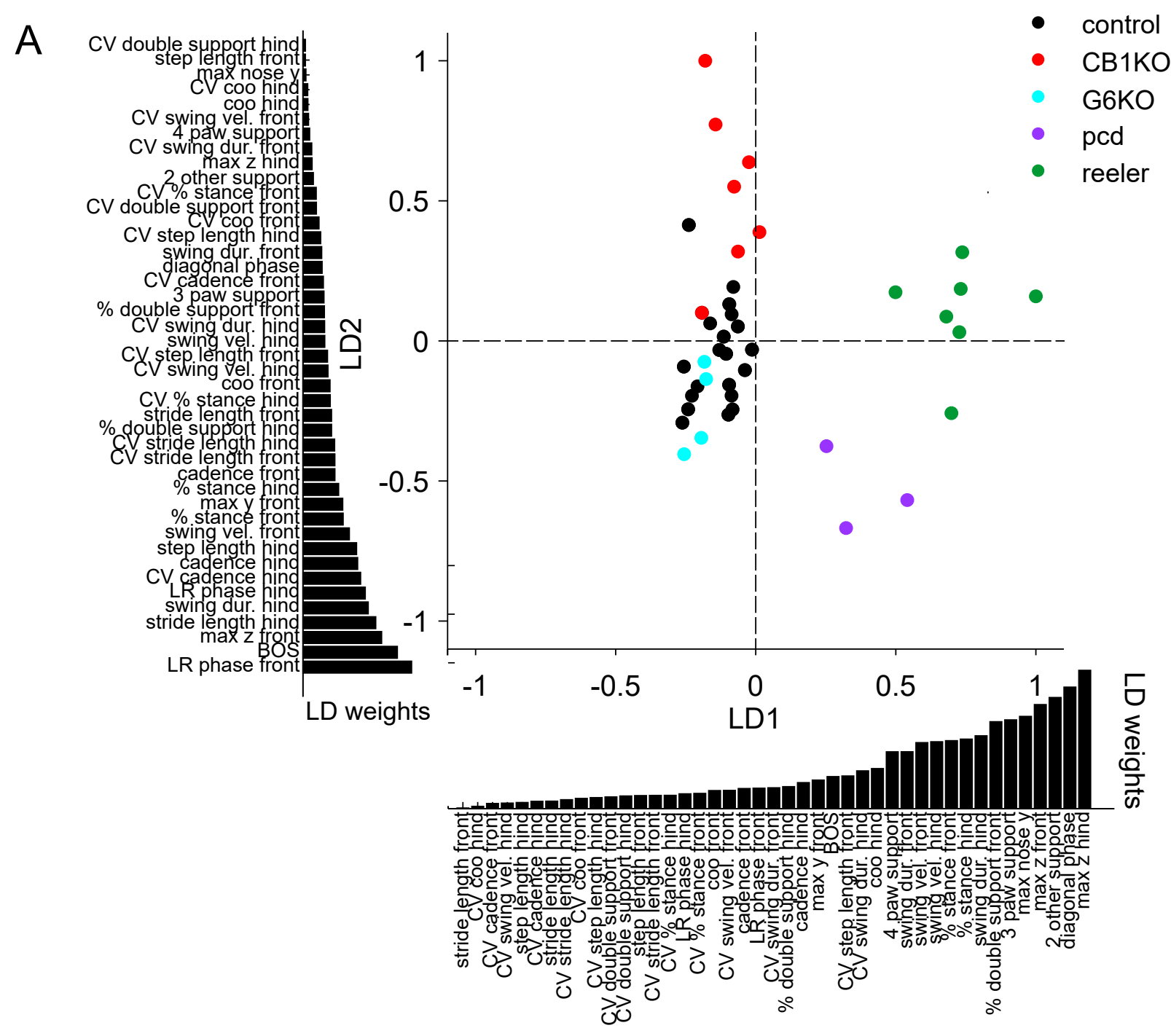

B

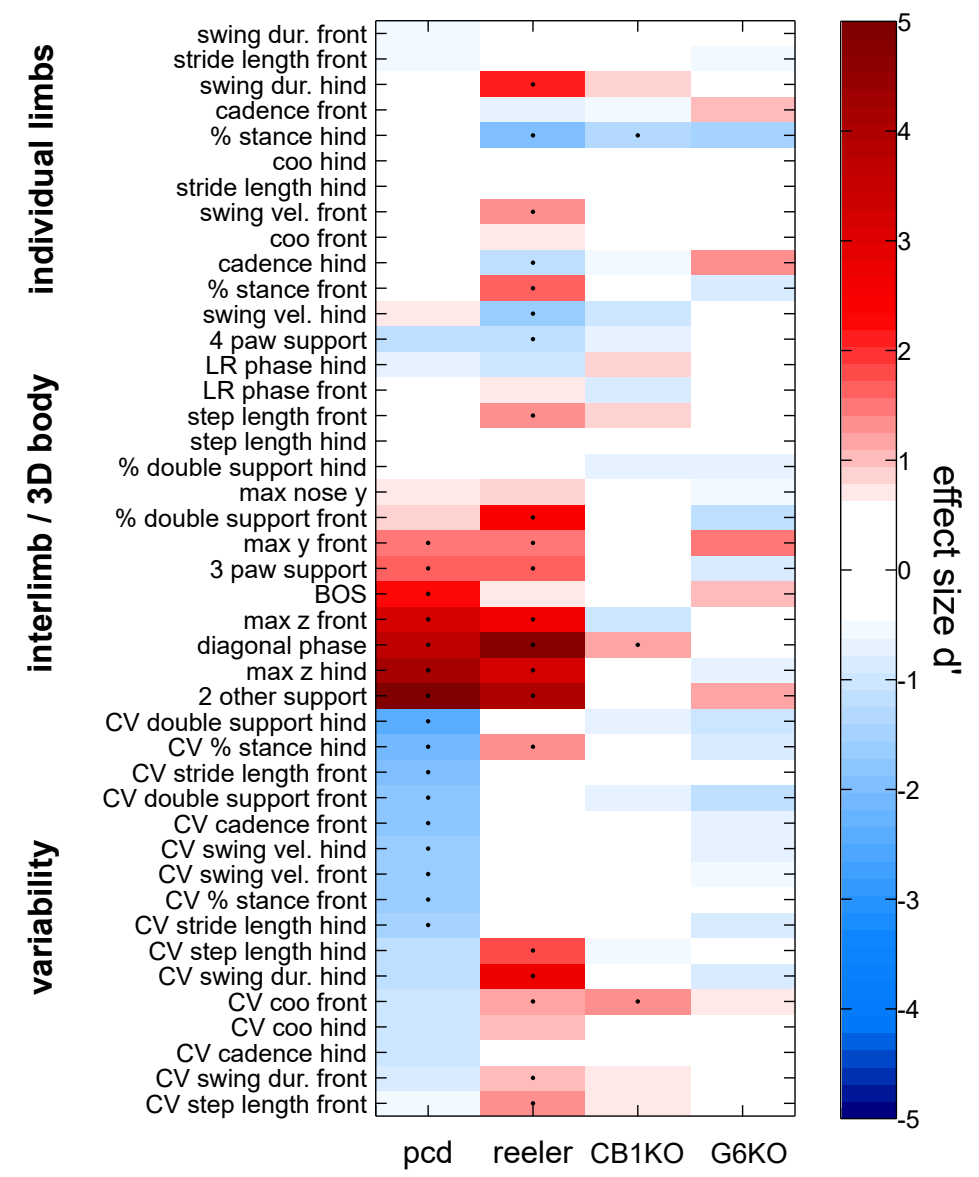


bioRxiv preprint doi: https://doi.org/10.1101/511113; this version posted September 27, 2020. The copyright holder for this preprint (which was not certified by peer review) is the author/funder, who has granted bioRxiv a license to display the preprint in perpetuity. It is made available under aCC-BY-NC 4.0 International license.
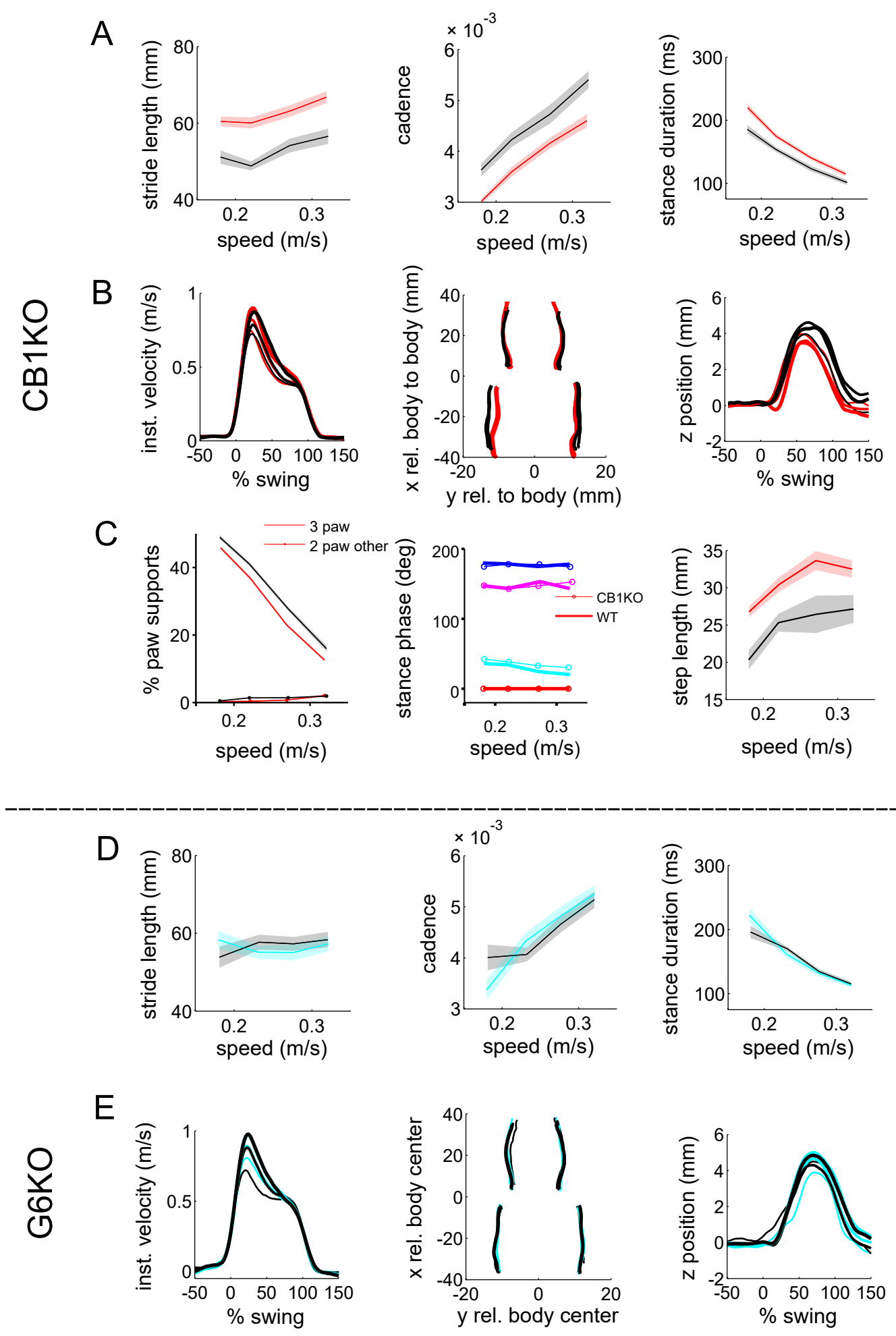

F
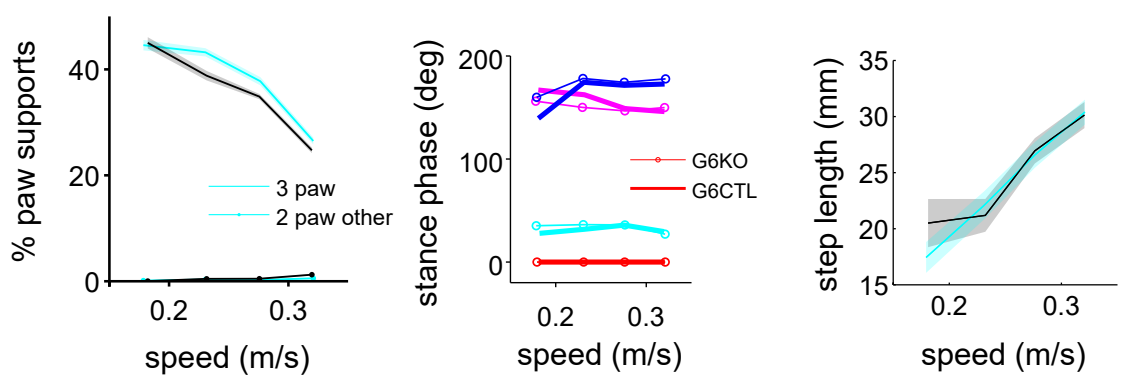